\title{
Phylogeny of the cetrarioid core (Parmeliaceae) based on five genetic markers
}

\author{
Arne THELL, Filip HÖGNABBA, John A. ELIX, \\ Tassilo FEUERER, Ingvar KÄRNEFELT, Leena MYLLYS, \\ Tiina RANDLANE, Andres SAAG, Soili STENROOS, \\ Teuvo AHTI and Mark R. D. SEAWARD
}

\begin{abstract}
Fourteen genera belong to a monophyletic core of cetrarioid lichens, Ahtiana, Allocetraria, Arctocetraria, Cetraria, Cetrariella, Cetreliopsis, Flavocetraria, Kaernefeltia, Masonhalea, Nephromopsis, Tuckermanella, Tuckermannopsis, Usnocetraria and Vulpicida. A total of 71 samples representing 65 species (of 90 worldwide) and all type species of the genera are included in phylogentic analyses based on a complete ITS matrix and incomplete sets of group I intron, $\beta$-tubulin, GAPDH and mtSSU sequences. Eleven of the species included in the study are analysed phylogenetically for the first time, and of the 178 sequences, 67 are newly constructed. Two phylogenetic trees, one based solely on the complete ITS-matrix and a second based on total information, are similar, but not entirely identical. About half of the species are gathered in a strongly supported clade composed of the genera Allocetraria, Cetraria s. str., Cetrariella and Vulpicida. Arctocetraria, Cetreliopsis, Kaernefeltia and Tuckermanella are monophyletic genera, whereas Cetraria, Flavocetraria and Tuckermannopsis are polyphyletic. The taxonomy in current use is compared with the phylogenetic results, and future, probable or potential adjustments to the phylogeny are discussed. The single non-DNA character with a strong correlation to phylogeny based on DNA-sequences is conidial shape. The secondary chemistry of the poorly known species Cetraria annae is analyzed for the first time; the cortex contains usnic acid and atranorin, whereas isonephrosterinic, nephrosterinic, lichesterinic, protolichesterinic and squamatic acids occur in the medulla. Notes on the anatomy of Cetraria annae and Flavocetraria minuscula are also provided.
\end{abstract}

Key words: Cetraria s. lat., conidial shape, DNA sequences, lichen phylogeny, taxonomy

A. Thell (corresponding author) and I. Kärnefelt: The Biological Museums, Lund University, Östra Vallgatan 18-20, SE-223 61 Lund, Sweden. Email: arne.thell@botmus.lu.se

F. Högnabba, L. Myllys, S. Stenroos and T. Ahti: Botanical Museum, Finnish Museum of Natural History, P.O. Box 7, FI-000 14 University of Helsinki, Finland.

J. A. Elix: Research School of Chemistry, Building 33, Australian National University, Canberra, ACT 0200, Australia.

T. Feuerer: Hamburg Univesity, Biozentrum Klein Flottbek, Department of Botany and Botanical Garden, Ohnhorststrasse 18, D-22609 Germany.

T. Randlane and A. Saag: Institute of Ecology and Earth Sciences, University of Tartu, Lai Street 38, 51005 Tartu, Estonia.

M. R. D. Seaward: Department of Archaeological, Geographical \& Environmental Sciences, University of Bradford, Bradford, BD7 1DP, UK.

\section{Introduction}

\section{The delimitation of the Parmeliaceae}

The Parmeliaceae is the largest (c. 2300 species) and most intensely studied of all lichen families. It has a characteristic ascoma ontogeny, a cupular exciple and forms a monophyletic clade, including recent segregates such as Alectoriaceae, Hypogymniaceae and Usneaceae (Crespo et al. 2007). The number of genera in the family increased from c. 20 in the early 1970 s to $c .90$ at the end of the last century (Elix 1993; Henssen \& Jahns 1974; Kärnefelt \& Thell 1992; Thell et al. 2004). Phylogenetic studies based on DNA sequences resulted in both synonymization and the creation of new genera. However, the number of genera has decreased over the last decade, but the taxonomy is still 
far from settled, as shown by adjustments made as a result of several large phylogenetic investigations. Thallus-form groups, alectorioid, cetrarioid, hypogymnioid, parmelioid and usneoid lichens, have often been discerned in the family, which to some degree correspond to the family names previously segregated from the Parmeliaceae (Thell et al. 2004). The mainly foliose parmelioid group constitutes the major part of the family, comprising c. 1500 species, of which 800 belong to the largest genus in the family, Xanthoparmelia (Vain.) Hale (Crespo et al. 2007). Most of the fruticose members, mainly alectorioid and usneoid, are gathered in the genera Alectoria Ach., Bryoria Brodo \& D, Hawksw. and Usnea Adans., the last perhaps comprising as many as 600 species (Wirtz et al. 2006). Monophyletic cores of the thallusform groups have been identified with the aid of different molecular markers, but all of them nested within the Parmeliaceae (Blanco et al. 2004a, 2005; Crespo et al. 2007; Divakar et al. 2006; Ohmura 2002; Ohmura \& Kanda 2004). The sister family of the Parmeliaceae is the Lecanoraceae wherein the genus Protoparmelia M. Choisy is probably most closely related to the Parmeliaceae (Arup et al. 2007; Crespo et al. 2007).

\section{The cetrarioid core}

The morphological group 'cetrarioid lichens' contains $c .135$ species spread over 20 genera, of which $c .90$ species and 14 genera form a monophyletic clade (Randlane et al. 1997; Thell et al. 2002; 2004) (Table 1). Thus, eight genera, Asahinea W. L. Culb. \& C. F. Culb., Bryocaulon Kärnefelt, Cetrelia W. L. Culb. \& C. F. Culb., Coelopogon Brusse \& Kärnefelt, Cornicularia (Schreb.) Hoffm., Dactylina Nyl., Esslingeriana Hale \& M. J. Lai, Parmelaria D. D. Awasthi and Platismatia W. L. Culb. \& C. F. Culb., traditionally known as cetrarioid, are spread within different clades in the Parmeliaceae, without having any close affinities to each other. Some cetrarioid species are combined in non-cetrarioid genera, such as Himantormia deusta (Hook. f.) A. Thell \& Søchting, Melanelia agnata (Nyl.) A. Thell, M. culber- sonii (Hale) A. Thell and M. hepatizon (Ach.) A. Thell. The genus Parmelaria is closely related to Parmotrema A. Massal. s. lat. (Blanco et al. 2005). The genera Esslingeriana and Melanelia are sister groups to the core of cetarioid lichens and, according to a phylogenetic study of the Parmeliaceae (A. Crespo et al., unpublished), Dactylina is an additional genus that is closely related to the cetrarioid core.

\section{Molecular phylogeny vs. taxonomy}

Before the era of DNA sequencing, the systematics of macrolichens was based on morphology, anatomy and secondary chemistry, with an increased emphasis on reproductive structures in the 1980s and 1990s, frequently with a focus on ascus apex characters (Hafellner 1984; Kärnefelt \& Thell 1994; Thell et al. 1995c), which show little correlation with DNA sequences, both in the Parmeliaceae and in other lichen families (Thell et al. 2004; Lumbsch et al. 2007). Cetrarioid lichens probably show the greatest variation of asci and conidia in comparison with the other morphological groups of the Parmeliaceae. Somewhat unexpectedly, DNA based phylogeny of cetrarioid lichens shows a clear correlation with conidial shape (Thell et al. 2002).

Hitherto, taxonomic changes based on DNA sequences have not been peformed on a large scale, and have mainly been responsible for reducing the number of polyphyletic genera (Blanco et al. 2004b) or for lumping rather than splitting genera (Blanco et al. 2004a). Among cetrarioid lichens, Tuckneraria Randlane \& A. Thell was synonymized with Nephromopsis Müll. Arg., and Nimisia Kärnefelt \& A. Thell with Himantormia I. M. Lamb (Thell et al. 2007). A detailed history of the pre-DNA sequencing taxonomy of cetrararioid lichens is provided by Thell et al. (2002).

The aim of this paper is to present a complementary phylogeny of the monophyletic core of cetrarioid lichens and discuss the relationship of the taxonomy to phylogeny within the group. Eleven species are investigated for the first time (Table 2), Ahtiana 
TABLE 1. Genera and type species of the cetrarioid core of the Parmeliaceae

Genus

Type species

Ahtiana Goward, Bryologist 88: 370, 1985.

Allocetraria Kurok. \& M. J. Lai, Bull. Nat. Sci. Mus. Tokyo, ser. B 17: 60, 1991.

Arctocetraria Kärnefelt \& A. Thell, Bryologist 96: 402, 1993.

Cetraria Ach., Meth. Lich.: 292, 1803.

Cetrariella Kärnefelt \& A. Thell, Bryologist 96: 402, 1993.

Cetreliopsis M. J. Lai, Quart. F. Taiwan Mus. 33: 218, 1980.

Flavocetraria Kärnefelt \& A. Thell, Acta Bot. Fennica 150: 81, 1994.

Kaernefeltia A. Thell \& Goward, Bryologist 99: 125, 1996. Masonhalea Kärnefelt, Bot. Notiser 130: 102, 1977.

Nephromopsis Müll. Arg., Flora 74: 374, 1891.

Tuckermanella Essl. Mycotaxon 85: 135-136. 2003.

Tuckermannopsis Gyeln., Acta Fauna Fl. Univ., ser. 2

(Bot.), 1 (5/6): 6, 1933.

Usnocetraria M. J. Lai \& J. C. Wei, f. Nat. Taiwan Mus. 60: 45-61, 2007.

Vulpicida Mattsson \& M. J. Lai, Mycotaxon 46: 427, 1993.
Ahtiana sphaerosporella (Müll. Arg.) Goward Allocetraria stracheyi (Bab.) Kurok. \& M. J. Lai

Arctocetraria andrejevii (Oxner) Kärnefelt \& A. Thell

Cetraria islandica (L.) Ach

Cetrariella delisei (Schaer.) Kärnefelt \& A. Thell

Cetreliopsis rhytidocarpa (Mont. \& Bosch) M. J. Lai

Flavocetraria cucullata (Bellardi) Kärnefelt \& A. Thell

Kaernefeltia californica (Tuck.) A. Thell \& Goward

Masonhalea richardsonii (Hook.) Kärnefelt

Nephromopsis stracheyi (Bab.) Müll. Arg.

Tuckermanella weberi (Essl.) Essl.

Tuckermannopsis ciliaris (Ach.) Gyelnik

Usnocetraria oakesiana (Tuck.) M. J. Lai \& J. C. Wei

Vulpicida juniperinus (L.) Mattsson \& M. J. Lai aurescens (Tuck.) Randlane \& A. Thell, 'Cetraria' annae Zahlbr., Cetraria australiensis Kärnefelt, Cetraria crespoae (Barreno \& Vázquez) Kärnefelt, Cetraria laevigata Rass., Cetraria kamczatica Savicz, Cetreliopsis laeteflava (Zahlbr.) Randlane \& A. Saag, 'Flavocetraria' minuscula (Elenk. \& Savicz) Ahti, Poryadina \& Zhurb., 'Melanelia' sorediella (Lettau) V. J. Rico, van den Boom \& Barrasa, Tuckermannopsis ciliaris (Ach.) Gyeln. and Tuckermannopsis inermis (Nyl.) Kärnefelt.

\section{Material and Methods}

\section{Selected material and genetic markers}

The matrix composed of 77 samples, representing 71 species, including the outgroups, were selected to investigate the phylogeny within the monophyletic core Cetraria s. lat., represented by 65 of the 90 species worldwide. Eleven of the species have not been previously analyzed for their DNA, 67 of the 178 sequences are new, and mitochondrial DNA is used in this group for the first time (Table 2).

Representatives from five genera were selected as outgroups. Melanelia and Esslingeriana are sister groups to the monophyletic core of cetrarioid lichens according to earlier investigations (Blanco et al. 2005, 2006; Thell et al. 2002, 2004). The three genera, Alectoria, Cetrelia and Platismatia, all rather distantly related to the cetrarioid core, and not closely related with each other, were selected as an external outgroup.

Earlier molecular phylogenetic studies on the cetrarioid group constituted a base for the combined, complementary data set. Amplification of ITS sequences were easily performed for all species, whereas $\beta$-tubulin, GAPDH and mtSSU sequences were much more difficult to amplify, the latter marker sequenced for the cetrarioid core on a large scale for the first time. Group I intron sequences are absent from more than half of the species investigated (Thell 1999; Thell et al. 2000, 2002, 2004).

\section{DNA analysis}

\section{Extraction}

MagAttract 96 DNA Plant Extraction Kit from Qiagen (08/2003) was used. The samples were rigorously shaken in a vortex machine in $300 \mu$ extraction buffer incorporating one steel bead into each microtube; otherwise, the enclosed protocol for manual DNA purification was followed.

\section{Amplification}

$25 \mu \mathrm{l}$ PCR-reactions were prepared to amplify the nuclear ITS1-5.8S-ITS2 ribosomal DNA region. The primers ITS1F (Gardes \& Bruns 1993), ITS4 (White et al. 1991), bt3LM, bt10LM (Myllys et al. 2001), gpd1LM, gpd2LM (Myllys et al. 2002), and mrSSU1, mrSSU3 (Zoller et al. 1999) were used. Ready To Go PCR beads (in $0.2 \mathrm{ml}$ tubes) from Pharmacia Biotec Inc. were dissolved in $11.8 \mu \mathrm{l}$ distilled water, $0.35 \mu \mathrm{l}$ of a $16 \mu \mathrm{M}$ concentration of each of the primers. The ITS 
TABLE 2. Lichen material and sequences used in the analyses of the cetratoid core of the Parmeliaceae. Sequences with accession-numbers beginning with EU were produced in this study.

\begin{tabular}{|c|c|c|c|c|c|c|c|}
\hline Species & Specimen-ID & Extr. & Intron & ITS & bt & Gpd & $\mathrm{mtSSU}$ \\
\hline Alectoria ochroleuca & Austria, Tirol, Feuerer $\&$ Thell s. n. (HBG) & AT976 & - & AF457926 & AF457926 & AY249638 & - \\
\hline Cetrelia olivetorum & $\begin{array}{l}\text { Austria, Tirol, Feuerer } \& \text { Thell } 64372 \\
\text { (HBG) }\end{array}$ & AT913 & - & AF451763 & AF449716 & AY249611 & \\
\hline Platismatia glauca & Estonia, Tartumaa, Thell 9903 (TUR) & AT550 & - & $\mathrm{AF} 451758$ & $\mathrm{AF} 457925$ & AY249593 & \\
\hline Esslingeriana idahoensis & $\begin{array}{l}\text { Canada, British Columbia, Goward } 961348 \\
\text { (UBC) }\end{array}$ & AT146 & - & $\mathrm{AF} 227513$ & - & - & - \\
\hline Melanelia hepatizon & $\begin{array}{l}\text { Italy, Trentino Alto Adige, Feuerer } \mathbb{E} \text { Thell } \\
\quad 64248 \text { (HBG) }\end{array}$ & AT934 & $\mathrm{AF} 451776^{\star}$ & AF451776 & DQ004576 & DQ004577 & EU435364 \\
\hline M. sorediella & Andorra, Ordino, Rico (MAF-Lich 10592) & AT1917 & EU401769 & EU401769 & - & EU423865 & EU435369 \\
\hline M. stygia & $\begin{array}{l}\text { Italy, Trentino Alto Adige, Feuerer } \mathcal{E} \text { Thell } \\
\quad 64247 \text { (HBG) }\end{array}$ & AT922 & - & AF451775 & AY074778 & AY249607 & EU435365 \\
\hline Ahtiana aurescens & $\begin{array}{l}\text { USA, Michigan, Gogebic Co., Wetmore } \\
882794(\mathrm{MIN})\end{array}$ & FH195 & - & EU401756 & - & - & - \\
\hline A. pallidula & $\begin{array}{l}\text { USA, Montana, Sanders Co., Hauck } \\
\text { (private hb.) }\end{array}$ & AT1268 & - & AY353709 & - & AY249602 & - \\
\hline A. sphaerosporella & $\begin{array}{l}\text { Canada, British Columbia, Miao \& Taylor } \\
\text { (TDI-211) }\end{array}$ & AT73 & AF141859 & AF141859 & - & AY249604 & - \\
\hline A. flavonigrescens & China, Sichuan, Obermayer 08140 (GZU) & AT873 & - & $\mathrm{AF} 404127$ & - & - & - \\
\hline A. globulans & China, Sichuan, Obermayer 08137 (GZU) & AT870 & - & $\mathrm{AF} 404126$ & - & - & - \\
\hline A. madreporiformis & Austria, Tyrol, Obermayer 7746 (M) & AT973 & - & AF416460 & - & - & - \\
\hline A. sinensis & China, Sichuan, Obermayer 08148 (GZU) & AT868 & - & AF404125 & - & - & - \\
\hline A. stracheyi & $\begin{array}{l}\text { China, Sichuan, Hengduan Shan, } \\
\text { Obermayer } 8139 \text { (GZU) }\end{array}$ & AT875 & - & AF404129 & AF449733 & - & EU435368 \\
\hline Arctocetraria andrejevii & $\begin{array}{l}\text { Greenland, Qeqertannguit, Hansen, exs. } \\
836 \text { (LD-1001631) }\end{array}$ & AT1364 & - & DQ004575 & - & - & - \\
\hline A. nigricascens & $\begin{array}{l}\text { Canada, N. W. T., Melville Isl., Westberg } \\
1614 \text { (LD) }\end{array}$ & AT793 & $\mathrm{AF} 254628^{\star}$ & AF254628 & AF449728 & AY249599 & - \\
\hline Cetraria aculeata & $\begin{array}{l}\text { Spain, Castlla \& León, Feuerer s. n. } \\
\text { (LD-1196893) }\end{array}$ & AT1922 & - & EU401758 & - & - & - \\
\hline C. annae & $\begin{array}{l}\text { Russia, Baikal region, Urbanavicius } \\
\text { (LD-1271346) }\end{array}$ & FH194 & - & EU401759 & - & - & EU435375 \\
\hline
\end{tabular}


TABLe 2. Continued

\begin{tabular}{|c|c|c|c|c|c|c|c|}
\hline Species & Specimen-ID & Extr. & Intron & ITS & bt & Gpd & $\mathrm{mtSSU}$ \\
\hline C. arenaria & Canada, Ontario (TDI-220) & AT173 & $\mathrm{AF} 115758$ & $\mathrm{AF} 115758$ & - & - & - \\
\hline C. australiensis & $\begin{array}{l}\text { Australia, N. S. W., Kosciusko State Park, } \\
\text { Feuerer (HBG) }\end{array}$ & AT1696 & EU401760 & EU401760 & - & EU423860 & EU435366 \\
\hline C. crespoae & $\begin{array}{l}\text { Spain, Castilla Y Léon, Feuerer (LD- } \\
\text { 1199338) }\end{array}$ & AT1920 & - & EU401761 & - & EU423861 & EU435379 \\
\hline C. ericetorum & $\begin{array}{l}\text { Sweden, Skåne, Åhus, Thell \& Marth } 9928 \\
\text { (TUR) }\end{array}$ & AT544 & AF228296 & AF228296 & AF449740 & AY249594 & - \\
\hline C. islandica & $\begin{array}{l}\text { Estonia, Tartumaa, Taevaskoja, Thell } 9901 \\
\text { (TUR) }\end{array}$ & AT548 & AF228290 & AF228290 & AF449739 & - & - \\
\hline C. kamczatica & $\begin{array}{l}\text { USA, Alaska, Noatak Nat. Preserve, Ahti } \\
63296(\mathrm{H})\end{array}$ & AT1950 & EU401763 & EU401763 & - & - & - \\
\hline C. laevigata & Russia, Sakha Republic, Ahti $64755(\mathrm{H})$ & AT1952 & EU401764 & EU401764 & - & - & - \\
\hline C. muricata & $\begin{array}{l}\text { Spain, Castilla Y Léon, Feuerer (LD- } \\
\text { 1197733) }\end{array}$ & AT1921 & - & EU410409 & - & - & - \\
\hline C. nigricans & Canada, Baffin Island, Westberg 2377 (LD) & AT791 & - & AF457922 & - & - & - \\
\hline C. oakesiana & Slovenia, Kärnefelt 960306 (LD-1077935) & AT136 & - & $\mathrm{AF} 116179$ & AF449731 & - & - \\
\hline C. oakesiana & $\begin{array}{l}\text { Germany, Bavaria, Oberbayern, v. Brackel } \\
\text { (IVL) }\end{array}$ & AT1915 & - & EU401757 & - & EU423859 & EU435374 \\
\hline C. obtusata & Austria, Tyrol, Feuerer $\mathcal{E}$ Thell s. n. (HBG) & AT990 & AF449739 & AF449739 & - & - & EU435378 \\
\hline C. odontella & $\begin{array}{l}\text { Finland, E. H., Sysmä, Haikonen } 23297 \\
(\mathrm{H})\end{array}$ & AT1694 & EU401765 & EU401765 & EU410411 & EU423863 & EU435367 \\
\hline C. sepincola & $\begin{array}{l}\text { Finland, Varsinais-Suomi, Puolasma } \mathcal{E} \\
\text { Thell } 0202 \text { (HBG) }\end{array}$ & AT1248 & - & EU401766 & - & EU423864 & EU435371 \\
\hline Cetrariella commixta & $\begin{array}{l}\text { Finland, Tavastia australis, Haikonen } \\
19093(\mathrm{H})\end{array}$ & AT720 & - & AF451796 & AF449735 & AY249596 & - \\
\hline C. delisei & $\begin{array}{l}\text { Iceland, S. Mulasysla, Thell } 9714 \text { (LD- } \\
\text { 1016978) }\end{array}$ & AT234 & - & AF228305 & AF449737 & AY249595 & EU435368 \\
\hline C. delisei & $\begin{array}{l}\text { USA, Alaska, Noatak, Holt } 23063 \text { (LD- } \\
\text { 1190098) }\end{array}$ & AT1913 & - & EU401767 & - & - & - \\
\hline C. fastigiata & Finland, KiL, Haikonen $24443(\mathrm{H})$ & AT1951 & - & EU401768 & - & - & EU435370 \\
\hline Cetreliopsis asahinae & South Korea (Hur 040500, unpubl.) & & & DQ394386 & & & \\
\hline C. laeteflava & $\begin{array}{l}\text { Taiwan, Kaoshiung County, Lai (private } \\
\text { hb.) }\end{array}$ & FH124 & - & EU401770 & - & - & EU435372 \\
\hline
\end{tabular}


TABLE 2. Continued

\begin{tabular}{|c|c|c|c|c|c|c|c|}
\hline Species & Specimen-ID & Extr. & Intron & ITS & bt & Gpd & $\mathrm{mtSSU}$ \\
\hline C. rhytidocarpa & $\begin{array}{l}\text { Philippines (Bawingan CL0582, Mol. Phyl. } \\
\text { Evol. 44) }\end{array}$ & & & DQ980008 & & & \\
\hline Flavocetraria cucullata & Russia, Sakha Republic, Ahti 61793 (H) & FH89 & - & EU401771 & - & - & EU435382 \\
\hline F. cucullata & $\begin{array}{l}\text { Austria, Tyrol, Feuerer \& Thell } 64185 \\
\text { (HBG) }\end{array}$ & AT932 & - & AF451793 & - & AY249601 & - \\
\hline F. minuscula & Russia, Sakha Republic, Ahti $61573(\mathrm{H})$ & FH90 & - & EU401772 & - & - & EU435381 \\
\hline F. minuscula & Russia, Sakha Republic, Ahti $61682(\mathrm{H})$ & FH91 & - & EU401773 & - & - & - \\
\hline F. minuscula & USA, Alaska, Zhurbenko $04204(\mathrm{H})$ & FH93 & - & EU401774 & - & - & - \\
\hline F. nivalis & $\begin{array}{l}\text { Iceland, S. Thingeyar sysla, Frödén } 643 \\
\text { (LD-1025426) }\end{array}$ & AT700 & - & AF451794 & - & - & EU435383 \\
\hline Kaernefeltia merrillii & $\begin{array}{l}\text { Spain, Madrid, El Berrueco, Thell } 0501 \text { et } \\
\text { al. (LD-1038537) }\end{array}$ & AT1918 & DQ395292* & DQ395292 & EU410412 & EU423866 & EU435380 \\
\hline K. californica & $\begin{array}{l}\text { USA, Oregon, Lincoln Co., McCune } 27703 \\
\text { (LD-1045103) }\end{array}$ & AT1703 & - & DQ004571 & - & - & - \\
\hline Masonhalea richardsonii & $\begin{array}{l}\text { Canada, Yukon Territory, Westberg } 1246 \\
\text { (LD) }\end{array}$ & AT792 & - & AF254617 & AF449730 & AY249598 & - \\
\hline Nephromopsis ahtii & $\begin{array}{l}\text { Bhutan, Paro Distr., Søchting } 8489 \text { (LD- } \\
\text { 1061438) }\end{array}$ & AT607 & AF404123 & AF404123 & - & - & - \\
\hline N. komarovii & $\begin{array}{l}\text { Russia, Primorie, Skirina } 10972 \text { (LD- } \\
\text { 1000141) }\end{array}$ & AT621 & & $\mathrm{AF} 451779$ & AF449722 & - & - \\
\hline N. laureri & $\begin{array}{l}\text { Italy, Trentino-Alto Adige, Feuerer } \mathcal{E} \text { Thell } \\
64288 \text { (HBG) }\end{array}$ & AT938 & AF451786 & AF451786 & AF449724 & DQ004529 & - \\
\hline N. leucostigma & $\begin{array}{l}\text { Bhutan, Thimpu Distr., Søchting } 9151 \\
\text { (LD-1003792) }\end{array}$ & AT604 & $\mathrm{AF} 451777$ & AF449716 & DQ004583 & & - \\
\hline N. melaloma & $\begin{array}{l}\text { Bhutan, Thimpu Distr., Søchting } 9181 \\
\text { (LD-1056669) }\end{array}$ & AT430 & $\mathrm{AF} 451778$ & AF449720 & & & - \\
\hline N. morrisonicola & China, Sichuan, Obermayer 8279 (GZU) & AT903 & - & AF451780 & - & - & - \\
\hline N. nephromoides & The Philippines, Ejem s. n. (H). & AT1693 & - & DQ004574 & - & - & - \\
\hline N. ornata & $\begin{array}{l}\text { Russia, Primorye, Kudryavtseva } 10980 \\
\text { (LD-1022832) }\end{array}$ & AT624 & - & AF451783 & AF449721 & - & - \\
\hline N. pallescens & Bhutan, Søchting 8206 (C) & AT618 & - & AF451784 & - & DQ004578 & - \\
\hline docomplicata & China, Sichuan, Obermayer 08276a (GZU) & AT907 & - & AF404131 & AF449725 & AY249603 & - \\
\hline N. stracheyi & Bhutan, Thimpu, Søchting 8095 (C) & AT606 & $\mathrm{AF} 451785^{\star}$ & AF451785 & - & AY249605 & EU435373 \\
\hline
\end{tabular}


TABLE 2. Continued

\begin{tabular}{|c|c|c|c|c|c|c|c|}
\hline Species & Specimen-ID & Extr. & Intron & ITS & bt & Gpd & $\mathrm{mtSSU}$ \\
\hline Tuckermannopsis americana & $\begin{array}{l}\text { Canada, British Columbia, Goward } 961350 \\
\text { (UBC) }\end{array}$ & AT148 & AF072233 & AF072233 & AF449726 & - & - \\
\hline T. chlorophylla & $\begin{array}{l}\text { South Africa, Western Cape, Feuerer } E \\
\text { Thell s. n. (HBG) }\end{array}$ & AT1022 & - & AF451789 & AF449727 & AY249600 & - \\
\hline T. ciliaris & $\begin{array}{l}\text { USA, N. Carolina, 2004-10-17, Fraker et } \\
\text { al. (AFTOL proj.) }\end{array}$ & - & FJ005090 & & - & - & - \\
\hline T. inermis & $\begin{array}{l}\text { USA, Alaska, Noatak Nat. Pr., Holt } 23441 \\
\text { (LD-1190038) }\end{array}$ & AT1912 & - & EU401762 & EU410410 & EU423862 & EU435376 \\
\hline T. orbata & USA, Montana, Hauck s. n. (private hb.) & AT1067 & DQ004572* & DQ004572 & - & - & - \\
\hline T. platyphylla & $\begin{array}{l}\text { Canada, British Columbia, Thell \& Veer } \\
9643 \text { (LD-1058556) }\end{array}$ & AT43 & $\mathrm{AF} 072235$ & $\mathrm{AF} 072235$ & - & - & - \\
\hline T. platyphylla & $\begin{array}{l}\text { Canada, British Columbia, Thell } 9675 \\
\text { (LD-1096447) }\end{array}$ & AT75 & - & AF072236 & AF449741 & DQ004581 & - \\
\hline T. subalpina & $\begin{array}{l}\text { Canada, British Columbia, Thell } 9606 \\
\text { (LD) }\end{array}$ & AT109 & AF072237 & AF072237 & - & - & - \\
\hline Tuckermanella coralligera & $\begin{array}{l}\text { USA, New Mexico, Worthington } 28821 \\
\text { (ASU) }\end{array}$ & AT1158 & $\mathrm{AF} 457924^{\star}$ & AF457924 & - & DQ004582 & - \\
\hline T. weberi & $\begin{array}{l}\text { USA, Arizona, Westberg } 548 \text { (LD- } \\
\text { 1012687) }\end{array}$ & AT614 & - & AF451792 & - & - & - \\
\hline Vulpicida canadensis & $\begin{array}{l}\text { Canada, British Columbia, Thell \& Veer } \\
96250 \text { (LD) }\end{array}$ & AT36 & - & AF072238 & - & - & - \\
\hline$V$. juniperinus & $\begin{array}{l}\text { Finland, Varsinais-Suomi, Lohja, Pykälä } \\
21426(\mathrm{H})\end{array}$ & AT1695 & - & EU401775 & - & - & - \\
\hline$V \cdot$ pinastri & Sweden, Scania, Thell 9604 (LD-1056353) & AT02 & AF139031 & AF139031- & - & - & - \\
\hline V. tubulosus & $\begin{array}{l}\text { Austria, Tyrol, Innsbruck, Feuerer \& Thell } \\
\text { s. n. (HBG) }\end{array}$ & AT933 & $\mathrm{AF} 404132^{\star}$ & AF404132 & AF449736 & - & - \\
\hline$V$. viridis & $\begin{array}{l}\text { USA, Connecticut, Tolland Co., Feuerer } \\
\text { s. n. (HBG) }\end{array}$ & AT1291 & DQ004573* & DQ004573 & - & DQ004580 & - \\
\hline
\end{tabular}

^Unpublished intron-sequences obtained from old ITS sequences. 
fragments were amplified with a Perkin-Elmer Gene Amp PCR System 9700 thermal cycler. 12.5 $\mu$ of the concentrated DNA extractions were added to the solution. The PCR program described by Ekman (2001) was employed: after a $2 \mathrm{~min}$. hold at $94^{\circ} \mathrm{C}$, six cycles followed with denaturation at $94^{\circ} \mathrm{C}$ for $60 \mathrm{sec}$., annealing at $62^{\circ}-56^{\circ} \mathrm{C}$ for $60 \mathrm{sec}$. (decreasing $1^{\circ} \mathrm{C}$ per cycle), and an extension at $72^{\circ} \mathrm{C}$ for $105 \mathrm{sec}$., followed by 34 cycles with denaturation at $94^{\circ} \mathrm{C}$ for 30 sec., annealing at $56^{\circ} \mathrm{C}$ for $30 \mathrm{sec}$. and extension at $72^{\circ} \mathrm{C}$ for $105 \mathrm{sec}$.; finally, a $10 \mathrm{~min}$. hold at $72^{\circ} \mathrm{C}$ was performed before the PCR products were cooled to $4^{\circ} \mathrm{C}$.

\section{Purification and sequencing}

The PCR products were cleaned with PCR clean-up NucleoFast 96 PCR Purification Kit from MachereyNagel following the user manual (2002/3/Rev. 01. p.12). $50 \mu \mathrm{TE}$ buffer was applied to each sample prior to the standard procedure for purification of PCR products under vacuum, which was followed, except for the second, optional, washing step, with purified water. The purified samples were collected in $50 \mu \mathrm{l}$ water and the amount of DNA was measured in an Eppendorf BioPhotometer. The concentrations ranged between 18 and $54 \mathrm{ng} / \mu \mathrm{l}$. The amount of DNA for sequencing, $1 \mathrm{ng} / \mathrm{base}$ pair, was dried for $1 \mathrm{hr}$ at $65^{\circ} \mathrm{C}$. Finally, the DNA-fragments were sent to Macrogen to be sequenced, using the same primers as for the amplification.

\section{Phylogeny}

The phylogenetic analyses of the manually aligned sequences were done with PAUP version $4.0 \mathrm{~b}$ (Swofford 1998). Trees were calculated using the general heuristic search option and the TBR branch swapping method, whereas gaps were treated as missing characters. Bootstrap analyses with 1000 replicates were performed using the same settings. Support values of 50 or above are marked in the consensus trees (Figs. $1 \& 2$ ). Two phylogenies are presented, the first based on the complete ITS matrix and and a second using all the DNA sequences.

To complement the parsimony analysis, data were analysed using a Bayesian approach (Larget \& Simon 1999), MrBayes 3.1 program. Posterior probabilities were approximated by sampling trees using a variant of the Markov Chain Monte Carlo (MCMC) method called Metropolis-coupled Markov Chain Monte Carlo (MCMCMC). The following priors were used: flat Dirichlets for the substitution rate matrix and nucleotide frequencies, uniform $(0,200)$ and $(0,1)$ distributions for the gamma curve shape parameter and proportion of invariable sites, an exponential distribution with mean $0 \cdot 1$ for the branch lengths, and a uniform distribution across tree topologies. The following settings were applied: the best-fit model (GTR+I+G) selected by AIC in MrModeltest 2.2; number of generations $=1100$ 000; number of simultaneous independent analyses $=2$; number of simultaneous chains $=4$; sample frequency $=100$; 'temperature' $=0 \cdot 2$. No molecular clock was assumed. The initial 2500 trees were discarded as burn-in before stability was reached. Using sumt option of MrBayes, a majority-rule consensus tree was calculated from 8500 trees sampled after reaching likelihood convergence to calculate the posterior probabilities of the tree nodes. Phylogenetic trees were drawn using TreeView.

\section{Anatomy}

Complementary anatomical studies were performed on two rare cetrarioid species, 'Cetraria' annae and 'Flavocetraria' minuscula. Anatomical sections, $15 \mu \mathrm{m}$ thick, produced using a Kryomate, Leitz freezing microtome, were mounted in lactophenol cotton-blue. The sections were studied with a Zeiss Axioscope light microscope.

\section{Secondary chemistry}

Secondary compounds of Cetraria annae were detected by means of high performance liquid chromatography (Elix et al. 2004).

\section{Taxonomy}

The taxonomy according to the latest world list of cetrarioid lichens (Randlane \& Saag 2002) is strictly used, with the addition of two recently added genera in the cetrarioid core, Tuckermanella and Usnocetraria (Esslinger 2003; Lai et al. 2007) and two species in other genera Cetrariella commixta (Nyl.) A. Thell \& Kärnefelt (Thell et al. 2004: 309) and 'Melanelia' sorediella (Rico et al. 2005: 205). Several existing, more natural combinations than the ones used here are discussed below. New combinations are needed for a few species, after careful evaluation of the genus concept. Taxonomic changes are postponed for the third updated world list of cetrarioid lichens (T. Randlane, A. Saag, A. Thell \& T. Ahti, unpublished).

\section{Results}

\section{Results of the phylogenetic analyses}

Phylogenetic analyses were performed on two data sets, the first on the complete ITS matrix, and the second based on the total matrix. The ITS analysis resulted in eight most parsimonious trees, all with a length of 1086 changes, $\mathrm{CI}=0 \cdot 4171, \mathrm{RI}=0 \cdot 6463$. Including gaps, the matrix was composed of 517 characters, of which 101 provided parsimony information. The analysis based on the combined data set resulted in 23 most parsimonious trees, having a length of 2923 changes, $\mathrm{CI}=0 \cdot 5279, \mathrm{RI}=0 \cdot 6067$. Including 


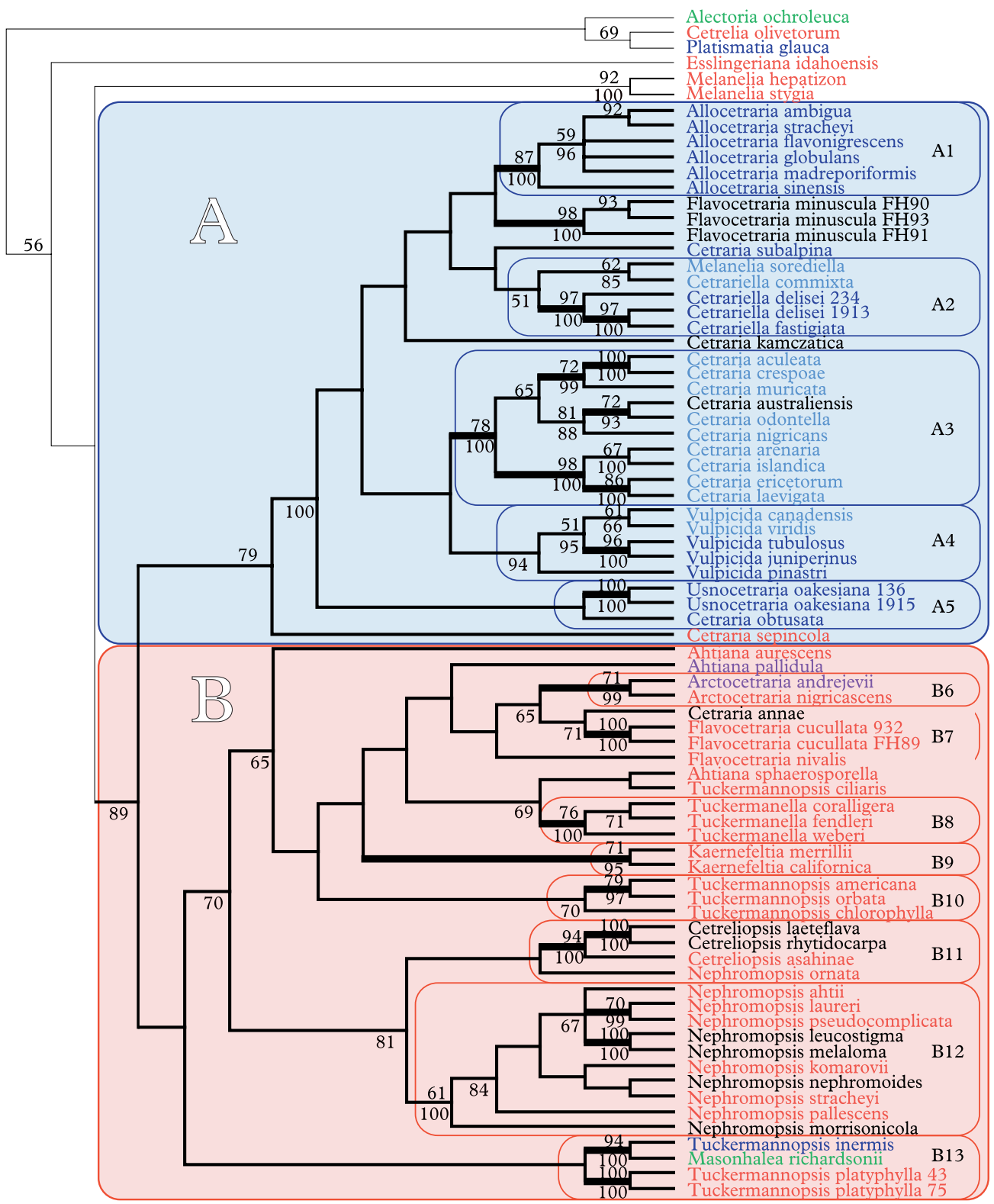

conidia with two swellings

conidia without swellings

conidia with one apical swelling

conidia with one central swelling

two or several conidial shapes observed

conidia not observed

FIG. 1. Consensus tree from eight most parsimonious trees using the heuristic search option in PAUP 4.0b, based on ITS sequences. Bootstrap support values $\geq 50$ from 1000 replicates are indicated above the branches. Posterior probability values $\geq 50 \%$ from the Bayesian analysis are indicated below the branches. Strongly supported clades

(bootstrap support $\geq 70 \%$ and posterior probabilities $\geq 95 \%$ in the Bayesian analysis) are marked in bold. 


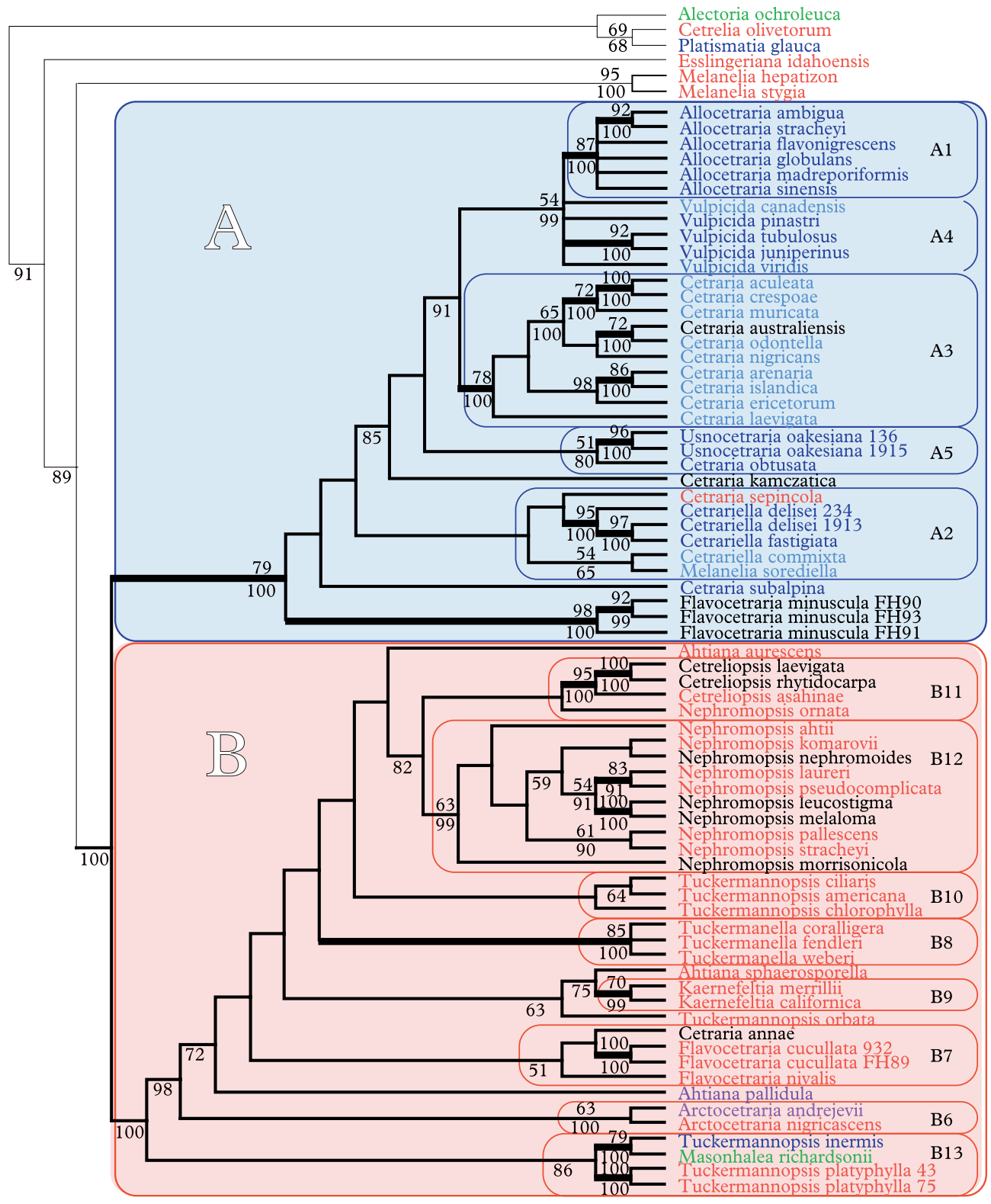

conidia with two swellings

conidia without swellings

conidia with one apical swelling

conidia with one central swelling

two or several conidial shapes observed

conidia not observed

FIG. 2. Consensus tree from 23 most parsimonious trees using the heuristic search option in PAUP 4.0b, based on the combined data matrix (Table 2). Bootstrap support values $\geq 50$ from 1000 replicates are indicated above the branches. Posterior probability values $\geq 50 \%$ from the Bayesian analysis are indicated below the branches. Strongly supported clades (bootstrap support $\geq 70 \%$ and posterior probabilities $\geq 95 \%$ in the Bayesian analysis) are marked in bold. 
gaps, the matrix was extended to 3314 characters, of which 644 proved to be parsimony informative.

The two consensus trees, calculated by PAUP, based on the ITS and combined data set, are similar, but not congruent, in their topologies (Figs $1 \& 2$ ). All groups supported by the bootstrap analysis are present in the PAUP consensus trees, whereas a few groups with support in the Bayesian analysis are not.

By performing MrBayes multiple runs starting from random trees, the inferences for independent runs were the same. Credible sets of trees for one run (7646 trees sampled) are as follows: $50 \%$ credible set contains 3146 trees, $90 \%$ credible set contains 6746 trees, 95\% credible set contains 7196 trees, 99\% credible set contains 7556 trees. Posterior probability values equal or above $50 \%$ are indicated on the consensus trees.

\section{Supported clades}

Most clades of the consensus trees calculated with PAUP were supported either by the bootstrap or Bayesian analyses. The clades that received bootstrap support equal or above $70 \%$ and/or posterior probabilities equal or above $95 \%$ in the Bayesian analysis were considered as strongly supported. The position of the species within the clades A1-4 and B9 and B12 differ slightly between the PAUP and Bayesian analyses. Generally, more clades were supported by the Bayesian analyses than by the bootstrap analyses.

\section{The cetrarioid core - ingroup}

The study group selected, comprising 14 genera (Table 1), was divided into two subgroups, the Cetraria and Nephromopsis clades, both with maximum posterior probabilities in the Bayesian analysis of the combined DNA-matrix (Figs. 1 \& 2, clades A \& B).

\section{A. The Cetraria clade}

This clade contains about half of the cetrarioid core and is divided mainly between five genera, Allocetraria, Cetraria, Cetrariella, Usnocetraria and Vulpicida, characterized by conidia with one swelling (apical or central, i.e. citriform, sublageniform or filiform), with Cetraria sepincola (Ehrh.) Ach., having dumb-bell shaped conidia, as the single known exception. The variation in morphology, anatomy and secondary chemistry is large and no key character for the clade can be presented. The species included are mainly from the Northern Hemisphere (often Himalayan) in their distribution ranges. The clade is strongly supported in the bootstrap analysis, 79 in both the ITS and combined DNA matrix analyses, as well as by the Bayesian analysis of the combined DNA matrix (maximum posterior probability).

\section{A1. The Allocetraria clade}

The bootstrap support value for Allocetraria is 87 in both the ITS and in the total analysis, although the genus is nested within Vulpicida in the PAUP analysis based on the entire matrix (Fig. 2). Six of the nine accepted species were investigated, and they all belong to this clade. The additional taxon, Usnocetraria oakesiana (Ach.) M. J. Lai \& J. C. Wei (formerly treated in Allocetraria) is absent from this clade in all our analyses, appearing as one of several singular species.

\section{A2. The Cetrariella clade}

Cetrariella is composed of a core of two closely related species, C. delisei (Schaer.) Kärnefelt \& A. Thell and C. fastigiata (Nyl.) Kärnefelt \& A. Thell, which are not separated by ITS data. The presence of Cetrariella commixta and 'Melanelia' sorediella in Cetrariella is weakly supported in this study. Cetraria sepincola was positioned in the same clade by the analysis based on the total matrix.

\section{A3. The Cetraria s. str. clade}

The genus Cetraria s. str. received moderate bootstrap support, 78 in both analyses, but is recognized in its entirety by the Bayesian analyses. Cetraria s. str. is divided into two species groups, centred around $C$. aculeata (Schreb.) Fr. and C. islandica (L.) Ach. All known members of the group, except for C. steppae (Savicz) Kärnefelt, were included in the study. Cetraria laevigata, for which only group I intron and ITS sequences were available, appears as a sister group to 
other Cetraria s. str. in the PAUP analysis based on the total evidence matrix, but is strongly supported as a member of the $C$. islandica group using the complete ITS matrix.

\section{A4. The Vulpicida clade}

Vulpicida is a chemically distinct genus and is supported as monophyletic by the Bayesian analysis of the ITS data, with posterior probability of 94 (Fig. 1). However, the genus appears to be paraphyletic in the PAUP analysis based on the entire matrix (Fig. 2) as Allocetraria is nested within the same clade. The positions of Vulpicida species remain unresolved in the PAUP analysis of the combined data set (Fig. 2). Five of the six species known worldwide were included in the analyses.

\section{A5. Usnocetraria oakesiana and Cetraria obtusata}

These two species form a separate clade according to three out of four analyses, but the support for the clade is weak (e.g. 51 bootstrap support and 80 posterior probability in the analyses of the combined matrix) and it is not definitely delimited from the other groups. The clade has a few nonmolecular characters in common, i.e. presence of sublageniform conidia and secalonic acid.

\section{B. The Nephromopsis clade}

This clade, including the rest of the cetrarioid core, the genera Ahtiana, Arctocetraria, Cetreliopsis, Flavocetraria, Kaernefeltia, $M a-$ sonhalea, Nephromopsis, Tuckermanella and Tuckermannopsis, lacks bootstrap support but is maximally supported by the Bayesian analysis based on the total matrix (Figs. $1 \&$ 2 ). The group is characterized by conidia with two apical or subapical swellings, dumb-bell to disc-bar shaped conidia. However, conidia of different types have been observed in two of the species, Ahtiana pallidula (Riddle) Goward \& A. Thell and Arctocetraria andrejevii (Oxner) Kärnefelt \& A. Thell (Kärnefelt 1979: 59; Thell et al. 1995a: 602, fig. 15), and no additional nonDNA character that characterizes the clade is known. Furthermore, some species included in the Masonhalea clade (see below) still have conidia without swellings or with one apical swelling. The position of this clade varies, being excluded from the Nephromopsis clade according to the Bayesian analysis of the ITS matrix and appearing as a sister clade to the remaining part of the cetrarioid core (such topology having, however, posterior probability of 89).

The species included in the Nephromopsis clade often have a western North American or South-east Asian distribution. The genera Arctocetraria, Cetreliopsis, Kaernefeltia, Nephromopsis s. str. and Tuckermanella form monophyletic clades according to the present taxonomy, whereas Nephromopsis ornata (Müll. Arg.) Hue is more closely related to Cetreliopsis than Nephromopsis, thus not belonging to Nephromopsis s. str. The genera Ahtiana, Flavocetraria and Tuckermannopsis appear to be polyphyletic.

\section{B6. The Arctocetraria clade}

Arctocetraria, a genus of only two species with an arctic distribution, is moderately supported by bootstrap analyses and strongly supported by Bayesian analyses. The inclusion of Arctocetraria within the genus Flavocetraria based exclusively on ITS sequences is only weakly supported.

\section{B7. The Flavocetraria clade}

All three accepted species were investigated. Two 'old' taxa, Flavocetraria cucullata (Bell.) Kärnefelt \& A. Thell and $F$. nivalis (L.) Kärnefelt \& A. Thell formed a separate clade together with the rare and recently rediscovered species 'Cetraria' annae. The third Flavocetraria species, the recently proposed ' $F$.' minuscula, is included in another major clade of the cetrarioid core - the Cetraria clade.

\section{B8. The Tuckermanella clade}

The bootstrap support of 76 for the North American genus Tuckermanella is weaker in the bootstrap analysis when based exclusively on ITS sequences, but when compared with the analysis inferred from the total matrix, the support value reached 85. Maximum 
support was received from the Bayesian analyses. Three of six accepted species were included.

\section{B9. The Kaernefeltia clade}

Kaernefeltia is an additional genus composed of two species. Like Arctocetraria, the genus received strong support by both bootstrap and Bayesian analyses.

\section{B10. The Tuckermannopsis clade}

Altogether 25 species have been combined in the genus, only eight are included in the genus in the strict sense (Randlane \& Saag 2003). Four 'true' Tuckermannopsis species, T. americana (Spreng.) Hale, T. chlorophylla (Willd.) Hale, T. ciliaris and T. orbata (Nyl.) M. J. Lai, were investigated in this study. Three species (in various combinations) are included in the Tuckermannopsis clade in different analyses (Figs. 1-2). The clade is, however, only weakly supported.

\section{B11. The Cetreliopsis clade}

The monophyletic status of this East Asian genus is strongly supported by all the analyses. The genus could be seen as nested within Nephromopsis s. lat. because $N$. ornata is positioned as a sister group to Cetreliopsis. However, the support for the common clade of Cetreliopsis-Nephromopsis (B11 \& B12) is lower than acceptable. Three species of seven worldwide were included in the analyses.

\section{B12. The Nephromopsis s. str. clade}

Eleven of the 19 species were analysed. The clade, including 10 taxa ( $N$. ornata excepted), received weak support, slightly above 60 , in both bootstrap analyses, but high posterior probabilities (99 and 100) in the Bayesian analyses.

\section{B13. Masonhalea richardsonii and \\ Tuckermannopsis inermis}

Masonhalea richardsonii (Hook.) Kärnefelt, a species characterized by bacillariform conidia, and Tuckermannopsis inermis, with sublageniform conidia, form a clade supported by all analyses. However, the two species have no non-DNA characters in common except for their arctic distribution. Both types of conidia, bacillariform and sublageniform, differ from that observed in the major Nephromopsis clade (clade B on Figs 1 \& 2). The third taxon, Tuckermannopsis platyphylla (Tuck.) Hale, is related to these two taxa in three out of four analyses, but only with weak support.

\section{Discussion}

\section{Conidial shape and phylogeny}

The variation in conidial shape is greater in the cetrarioid core than in any other corresponding clade in the Parmeliaceae (Thell $1995 b$ ) and is the character that shows strongest correlation with DNA based phylogeny (Thell et al. 2002), as illustrated by the different colours in Figs. $1 \& 2$. The main difference between the conidia is the number of swellings: none, one or two. Conidia with two swellings are dominant among species of the major Nephromopsis clade (B). There are slight differences between them, sometimes discerned as dumb-bell and disc-bar shaped, but the swellings are always more or less apical and are treated as one type in this study. This type is characteristic of the genera Flavocetraria, Kaernefeltia, Nephromopsis, Tuckermanella and Tuckermannopsis.

The second type of conidium has one swelling that may be situated either apically or centrally. Conidia with one apical swelling are either sublageniform (bottle-shaped) if they are shorter than $12 \mu \mathrm{m}$ or filiform if they are longer than $12 \mu \mathrm{m}$. Sublageniform conidia occur in three genera of the Cetraria clade (A): Cetrariella, Usnocetraria and Vulpicida, as well as in Cetraria obtusata (Schaer.) v. d. Boom \& Sipman and C. subalpina Imshaug. Filiform conidia is a key character for distinguishing the genus Allocetraria. Conidia with a central swelling are fusiform, varying from short to oblong citriform; the latter is typical for Cetraria s. str., whereas the short citriform type is known from Cetrariella commixta, Vulpicida canadensis (Räsänen) J.-E. Mattsson and $V$. viridis (Swein.) J.-E. Mattsson.

The third type of conidium, without swellings (bacillariform), is rare in cetrarioid 
lichens, being restricted to Masonhalea richardsonii.

In spite of the strong correlation between conidial shape and DNA, there are notable exceptions, such as Cetraria sepincola, the only species with dumb-bell shaped conidia in the major Cetraria clade, Arctocetraria andrejevii, where both dumb-bell and oblong citriform conidia have been found, and Ahtiana pallidula, where different conidial shapes have been observed within the same pycnidium (Thell et al. 1995a). Obermayer (2008) recently reported variation in conidial shape within Cetraria islandica.

\section{Notes on the genera}

\section{Ahtiana Goward}

Ahtiana was originally proposed as a monotypic genus for $A$. sphaerosporella (Müll. Arg.) Goward, a species segregated from Parmelia Ach. (Goward 1985). The inclusion of two additional North American species, $A$. aurescens and $A$. pallidula (Thell et al. 1995a), based on their similar spherical ascospores and the presence of caperatic acid in the medulla, is not supported by cladistic analyses (Figs 1 \& 2); however, accommodating these taxa into any other genera has no support either. Returning to a monotypic Ahtiana, including only $A$. sphaerosporella, would seem attractive to lower the number of polyphyletic genera, but is not confirmed in the present study. Hale (in Egan 1987) combined several species in Tuckermanopsis including Ahtiana pallidula but not $A$. aurescens, and the only alternative combination for A. aurescens, namely Cetraria aurescens Tuck., would not be tenable if one preserves a multigenus concept within the cetrarioid core.

\section{Allocetraria Kurok. Eऽ M. F. Lai}

This genus includes nine species, mainly occurring at high altitudes, seven of which are endemic to the Himalayas (Kurokawa \& Lai 1991; Randlane \& Saag 2004). The type species, A. stracheyi (Bab.) Kurok. \& M. J. Lai, also occurs infrequently in North America, and A. madreporiformis (Ach.) Kärnefelt \& A. Thell is widespread in arctic and alpine areas of the Northern Hemisphere
(Randlane \& Saag 2004). Some species originally described in the genera Cetraria and Dactylina have been transferred to this genus on two occasions since the original circumscription of the genus (Thell et al. 1995b; Kärnefelt \& Thell 1996). One such species, $A$. oakesiana (Tuck.) Randlane \& A. Thell, differs in having shorter conidia (7-12 $\mu \mathrm{m}$ long) when compared with Allocetraria s. str. (12-21 $\mu \mathrm{m}$ long). The exclusion of $A$. oakesiana from the genus results in a strongly supported Allocetraria-clade (Figs $1 \& 2$ ). As presently delimited, Allocetraria is characterized by filiform conidia, slightly thicker at one end, and longer than in any other genus of the Parmeliaceae, except for Parmeliopsis, which has conidia of similar length

Lai et al. (2007) proposed the genus Usnocetraria to include 11 species formerly accommodated in Allocetraria, Cetraria, Nephromopsis and Tuckermannopsis, and returned A. madreporiformis to Dactylina. However, the position of $A$. madreporiformis close to the type species of the genus Allocetraria, A. stracheyi, was confirmed in a phylogenetic analysis by Saag et al. (2002). Therefore, the genus Usnocetraria is proposed here as being monotypic for U. oakesiana (see Usnocetraria).

\section{Arctocetraria Kärnefelt $\mathcal{E}$ A. Thell}

Arctocetraria was segregated from Cetraria because of differences in ascus structure, mainly the broader axial body, as well as the presence of bifusiform conidia (although the conidia are usually citriform in $A$. andrejevii), and the occurrence of norrangiformic and rangiformic acids in the medulla (Kärnefelt et al. 1993). The consensus tree based on ITS sequences suggests a relationship between Arctocetraria and Flavocetraria, but without bootstrap support. Both of these Cetraria-segregates are positioned outside the rather well supported Cetraria s. lat. clade in the phylogenetic trees (Fig. 1).

\section{Cetraria Ach.}

This traditional, well-known genus is characterized by the fatty acids, lichesterinic and protolichesterinic acids, in the medulla, and the fusiform, oblong citriform conidia, 
6-10 × 1 $\mu \mathrm{m} \quad$ (Kärnefelt 1979, 1986; Kärnefelt et al. 1992), often clavate, according to Obermayer (2008). The Cetraria s. str. clade (A3) is exclusively composed of the $C$. aculeata and C. islandica groups. However, in order to avoid the creation of a large number of new genera, Cetraria is considered to include some additional species, C. kamczatica, C. obtusata and C. sepincola, from the Cetraria s. lat. clade (A). They differ from Cetraria s. str. in both secondary chemistry and conidial shape, with $C$. sepincola being the most divergent in having dumb-bell shaped conidia. The name C. subalpina should be used instead of Tuckermannopsis subalpina (Imshaug) Kärnefelt, and 'Flavocetraria' minuscula is probably more appropriately accommodated in Cetraria than in any of the other genera from clade $\mathrm{A}$ or in Flavocetraria from clade B according to the results presented here.

\section{Cetrariella Kärnefelt $\mathcal{E}$ A. Thell}

This Cetraria segregate was proposed for the closely related species, Cetrariella delisei and $C$. fastigiata, characterized by broader asci and axial bodies than in Cetraria s. str., sublageniform conidia, and presence of gyrophoric and hiascic acids in the medulla (Kärnefelt et al. 1993). Subsequently, the former Cetraria commixta (Nyl.) Th. Fr. was shown to be in the same clade as Cetrariella delisei and $C$. fastigiata following a cladistic analysis based on DNA sequences, and the new combination in Cetrariella was proposed (Thell et al. 2004). Cetrariella commixta had earlier been transferred to Melanelia together with the superficially similar Melanelia agnata (Nyl.) A. Thell, M. culbersonii (Hale) A. Thell and M. hepatizon (Ach.) A. Thell (Thell 1995a).

Another taxon, formerly known as Cetraria commixta f. sorediella Lettau, was raised to species level as Melanelia sorediella (Rico et al. 2005). This species was subjected to DNA analysis in the present study and shown to be the closest relative of Cetrariella commixta, which would suggest that the two taxa evidently belong to the same genus. However, the position of both Cetrariella commixta and 'Melanelia' sorediella in the Cetrariella-clade has lower support than accepted values, and furthermore these locations are not supported by any non-DNA characters. If Cetrariella survives as a separate genus, it could be delimited either to include additionally ' $M$.' sorediella or retained exclusively for $C$. delisei and $C$. fastigiata. The present results support the latter solution as the phylogenetic position of Cetrariella commixta and 'M.' sorediella remains unresolved.

The consensus tree based on ITS sequences places Cetraria subalpina as a sister group to Cetrariella, a position which is not supported in the consensus tree based on the complete matrix.

\section{Cetreliopsis M. F. Lai}

Cetreliopsis is a genus of large foliose species which occur in the eastern and southeastern Asia (Randlane et al. 2001; Randlane \& Saag 2004). The genus was originally described as monotypic (Lai 1980), but was later re-evaluated and distinguished from Nephromopsis by the presence of pseudocyphellae on both sides of the thallus in combination with the presence of fumarprotocetaric acid in the medulla. The genus currently includes seven species with this combination of characters (Randlane et al. 1995; Lai \& Elix 2002; Randlane \& Saag 2003). Relatively few species, three out of a possible seven, were included in the present study but the genus has rather strong bootstrap support as it is currently circumscribed.

\section{Flavocetraria Kärnefelt \& $A$. Thell}

Hitherto, this genus was composed of three arctic-alpine species which occur mainly in the Northern Hemisphere. Two widely known taxa, $F$. cucullata and $F$. nivalis, are presumed to be closest relatives, with strong bootstrap support in earlier analyses (Kärnefelt et al. 1994; Thell \& Miao 1998; Thell et al. 2002; 2004; 2005). However, in this study, the situation is different because of the inclusion of two rare species, an amphi-Beringian ' $F$.' minuscula, and the recently rediscovered terricolous 'Cetraria' annae from Siberia. The latter is most closely related to $F$. cucullata with which it forms 
a weakly supported clade, together with $F$. nivalis. Following the results based on the combined data set, the most natural position for 'Cetraria' annae would be in Flavocetraria (for detailed information on ' $C$.' annae see below).

According to the present analyses, 'Flavocetraria' minuscula has no affinities with the genus Flavocetraria, but belongs to another major clade of the cetrarioid core, the Cetraria s. lat. clade (Fig $1 \& 2$ ); for further details on ' $F$.' minuscula see below. Thus as it currently stands, the genus Flavocetraria appears to be polyphyletic.

\section{Kaernefeltia $A$. Thell \& Goward}

Kaernefeltia is a genus of two closely related species which are characterized by conidia with two swellings (disc-bar shaped) and the presence of several distinctive fatty acids. Kaernefeltia merrilli (Du Rietz) A. Thell \& Goward is the more common species, with a remarkable disjunct distribution, occurring in western North America, from Baja California to northern British Columbia and eastwards to Saskatchewan, as well as in central Spain, whereas K. californica (Tuck.) A. Thell \& Goward is maritime along the Pacific coast in North America (Thell \& Goward 1996). The genus has moderate support in the present study.

\section{Masonhalea Kärnefelt}

Compared with the cetrarioid core, this monotypic genus has several unique characters, i.e. a freely-rolling (vagrant) habit, decorticate patches on the lower side, a thick, prosoplectenchymatous upper cortex composed of pachydermatous hyphae and bacillariform conidia (Kärnefelt 1977a, 1979). The presence of alectoronic acid is rare in the cetrarioid core, but is found in some genera and species, such as Cetrariella commixta, Nephromopsis pallescens (Schaer.) Park and Tuckermannopsis s. str. (Kärnefelt \& Thell 1993). The lateral position of the apothecia is a character in common with the closely related Tuckermannopsis inermis and some additional Tuckermannopsis species, as well as with the genera Cetreliopsis and Nephromopsis. The monotypic status of the genus is not supported phylogenetically according to the present study. However, another member of the well-supported Masonhalea clade, $T$. inermis, shares no non-molecular characters with $M$. richardsonii, except for the similar arctic, northern-Beringian distribution. The pseudocyphellae are conspicuous in both species, forming unique, large decorticate patches on the lower side of $M$. richardsonii, and a continuous line close to the margin of the lower side of $T$. inermis.

\section{Nephromopsis Müll. Arg.}

This genus is the second oldest of the group, originally described as monotypic (Müller 1891). The generic name was rarely used until re-established by Lai (1980) and re-delimited by Randlane et al. (1995). An outline of the genus, including distribution maps and keys is presented by Randlane \& Saag (1998). At that time Nephromopsis included the genus Cetrariopsis Kurok. More recently, the genus Tuckneraria Randlane \& A. Thell was synonymized with Nephromopsis and two new combinations were made, Nephromopsis leucostigma (Lév.) A. Thell \& Randlane and N. melaloma (Nyl.) A. Thell \& Randlane following a molecular analysis (Thell et al. 2005) so that Nephromopsis then included 19 species. The most closely related genus is Cetreliopsis, which is distinguished by the presence of pseudocyphellae on both upper and lower surfaces, and fumarprotocetraric acid in the medulla.

\section{Tuckermanella Essl.}

The genus Tuckermanella was recently described to accommodate six rather small, brown, adnate foliose species, apparently endemic to southern and western inland areas of North America (Esslinger 2003). The presence of mostly ellipsoid ascospores, submarginal and laminal pycnidia and continuous marginal pseudocyphellae distinguish this genus from Tuckermannopsis where most of these species had previously been accommodated. Three of the six species have been analyzed phylogenetically and form a wellsupported clade nested within the large Nephromopsis clade. 
Tuckermannopsis Gyeln.

This genus was little used until resurrected by Lai (1981). Since then it has been used as a 'dustbin' where various cetrarioid species (25 in total) of dubious generic position have been placed (Randlane \& Saag 2003). Kärnefelt \& Thell (2001) attempted to delimit the genus based on morphology and DNA sequences and listed seven species in Tuckermannopsis s. str., four of which have been investigated in this study: T. americana, $T$. chlorophylla, $T$. ciliaris and $T$. orbata. The three species excluded from our analyses are endemic to Japan, namely $T$. gilva (Asahina) M. J. Lai, T. microphyllica (W. L. Culb. \& C. F. Culb.) M. J. Lai and T. ulophylloides (Asahina) M. J. Lai. In addition, the DNA of two further rare species combined in Tuckermannopsis but evidently not belonging to the genus in a strict sense remain to be studied, the Japanese endemic T. platyphylloides (Asahina) M. J. Lai and the Chinese endemic, T. weii (X. Q. Gao \& L. H. Chen) Randlane \& Saag. Two additional species, $T$. inermis and $T$. platyphylla, were included in the present study but their generic positions still remains unclear.

The delimitation of Tuckermannopsis s. str. is difficult to determine. The Tuckermannopsis clade, including $T$. americana, $T$. chlorophylla and $T$. orbata according to analyses based on the ITS matrix, and T. americana, $T$. ciliaris and $T$. chlorophylla according the combined DNA matrix, has no acceptable support. The species are dispersed in the different analyses, among Ahtiana, Kaernefeltia and Tuckermanella (Figs $1 \& 2$ ). Tuckermannopsis inermis forms a supported clade together with Masonhalea richardsonii, while $T$. platyphylla is related to these taxa in three out of four analyses, but with only weak support. As with Cetraria, the polyphyly of Tuckermannopsis is currently accepted in order to avoid erecting several new genera.

\section{Usnocetraria M. F. Lai E C. F. Wei}

In a synopsis of Chinese cetrarioid lichens in a broad sense, the genus Allocetraria was re-delimited and the new genus Usnocetraria proposed (Lai et al. 2007). Usnocetraria oakesiana was selected as the type species of the genus. This species was not closely related to the three genera where it has previously been combined, i.e. Allocetraria, Cetraria s. str. and Tuckermanopsis. Consequently, Usnocetraria is proposed here as being monotypic for $U$. oakesiana, a disjunct alpine species in the Northern Hemisphere (Randlane \& Saag 2004). A second proposed species which was transferred from Nephromopsis, U. kurokawae (Shibuichi \& Yoshida) M. J. Lai \& J. C. Wei, endemic in Japan, was not supported by the present study. Nine additional taxa of different phylogenetic origins were listed under Usnocetraria as new combinations (Lai et al. 2007: 45), but are invalidly published as they lacked basionym citations. None of these species are closely related to $U$. oakesiana, whose closest relative is most likely Cetraria obtusata. The latter taxon occurs in the Alps and is very different from $U$. oakesiana in gross morphology, being erect fruticose, but it does have similar sublageniform conidia and contains secalonic acid in the medulla (v.d. Boom \& Sipman 1994).

\section{Vulpicida F.-E. Mattsson \& M. F. Lai}

This genus is characterized by the secondary chemistry, namely the presence of pulvinic and vulpinic acids, compounds derived from the shikimic acid pathway. The presence of these substances together with usnic acid give the thallus and medulla a shiny yellow or greenish yellow colour (Mattsson \& Lai 1993; Mattsson 1993). Five of the six known species were included in the present analyses. Two of these species, $V$. canadensis and $V$. viridis, are endemic to different parts of North America and characterized by short citriform conidia. The Eurasian $V$. juniperinus (L.) J.-E. Mattsson \& M. J. Lai and the disjunct European $V$. tubulosus (Schaerer) J.-E. Mattsson \& M. J. Lai are closely related, whereas the widespread $V$. pinastri (Scop.) J.-E. Mattsson \& M. J. Lai has a more isolated position within the genus. The sixth species, the Eurasian arctic-alpine $V$. tilesii (Ach.) J.-E. Mattsson \& M. J. Lai (Randlane \& Saag 2005), was not included.

The genus is supported as being monophyletic by the Bayesian analysis of the ITS data (Fig. 1), whereas the positions of the 


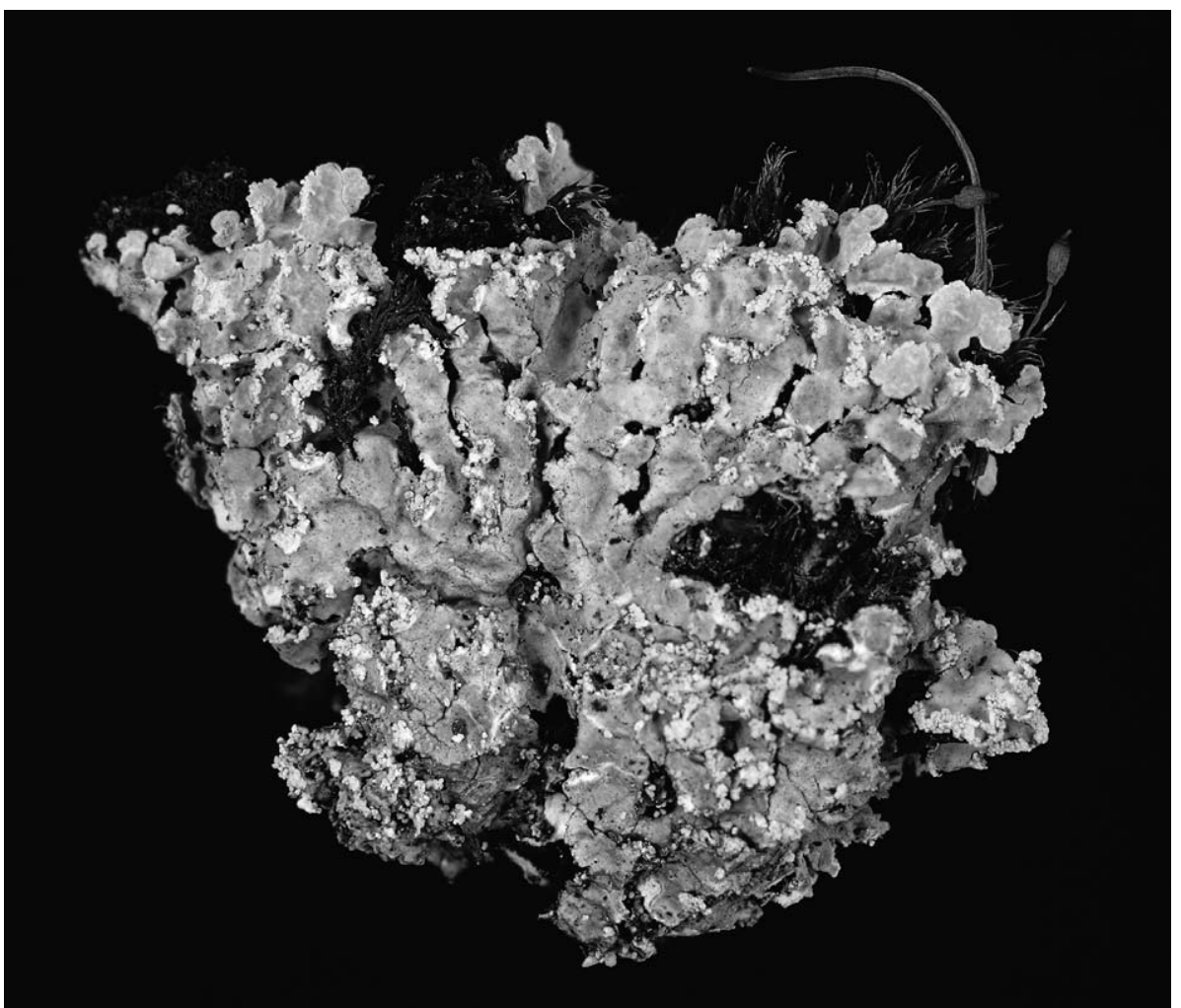

Fig. 3. Cetraria annae, Okinskii District, Russia, 18 viii 2007 Urbanavichus (LD-1271346, dupl. ex TU), $\times 4$.

species remained unresolved in the PAUP analysis of the combined data set because Allocetraria was nested within Vulpicida (Fig. 2).

\section{Comments on some rare and phylo- genetically interesting species}

\section{Cetraria annae Oxner}

Cetraria annae was forgotten soon after its description by Oxner (1933). However, this species was recently rediscovered after being collected again from the same area. The species is pale yellow, terricolous, and closely attached to the substratum (Fig. 3).

The thallus is foliose, to $3 \mathrm{~cm}$ wide, with narrow, rounded lobes, $1-3 \mathrm{~mm}$ wide and c. $300 \mu \mathrm{m}$ thick. Lobules are present, and are often constricted at the base. The lobe margins are somewhat crenulate. The soralia are conspicuous along margins and weakly labri- form; soredia are white, granular. Both upper and lower cortices are composed of mesodermatous paraplechtenchyma, with both layers c. $50 \mu \mathrm{m}$ thick. The medulla is white, and almost as compact as the cortical layers. Algal cells occur in clusters, 5-20 together, in the upper part of the medulla. No apothecia were seen, but the scattered, marginal, black pycnidia were pronounced, but lacked conidia.

Cetraria annae is positioned phylogenetically close to Flavocetraria cucullata. Chemical analysis of two specimens (Urbanavichus 1996, 2001; TU) revealed the presence of usnic acid [major], isonephrosterinic acid [major], lichesterinic acid [minor], atranorin [minor], squamatic acid [minor], protolichesterinic acid [trace] and nephrosterinic acid [trace]. Usnic, lichesterinic and protolichesterinic acids also occur in F. cucullata. However, the anatomical studies provided 
no confirmation of the weakly supported phylogenetic position of this species in Flavocetraria.

Specimens examined. Russia: Baikal region, River Levaya Anosovka, on riverbank rocks, 1996, Urbanavicius (TU, det. Randlane); Baikal Nature Reserve, in the vicinity of Lake Tschornaya, on mossy rocks, 2001, Urbanavicius, (TU, det. Randlane); Republic of Buriat, Okinskii district, River Zhom-Bolok, 52 $42^{\prime} 42.3^{\prime \prime} \mathrm{N}$ $99^{\circ} 17^{\prime} 37.3^{\prime \prime} \mathrm{E}$, on mossy rocks, 2007, Urbanavicius (TU, LD-1271346).

\section{Cetraria australiensis Kärnefelt}

This Australian endemic is morphologically very similar to $C$. odontella (Nyl.) Nyl. However, these two closely related species differ in their morphology, substratum and distribution, with $C$. australiensis being dorsiventral and growing on twigs or on soil in alpine habitats of Australia, whereas the lobes of the widely distributed, tuft-forming C. odontella are more or less isodiametric (Kärnefelt 1977b, 1986). One report of C. odontella from Australia, based on Group I and ITS sequences (Thell et al. 2000: AF228285), proved to be C. australiensis after comparison with the newly determined but identical ITS sequence performed in the present study, as well as by re-evaluating the morphology. The ITS sequences of the two species differ in two positions.

Flavocetraria minuscula (Elenk. E Savicz) Ahti, Poryadina \& Zhurb.

Flavocetraria minuscula, known earlier as a form or variety within $F$. cucullata, was raised to species status by Zhurbenko et al. (2005) because of its distinctive morphological characters, being smaller than $F$. cucullata with tube-like lobes, a pruinose surface and characteristic helmet-shaped, hooked lobe tips (Fig. 4).

The anatomy of $F$. minuscula was studied in the present work but no differences were found between the amphi-Beringian $F$. minuscula and the more widely distributed $F$. cucullata. The cortical layers of each are c. $50 \mu \mathrm{m}$ wide and are composed of mesodermatous paraplectenchyma, while the medulla is composed of densely interwoven, thick-walled hyphae and the algal cells are scattered in the upper part of the medulla.

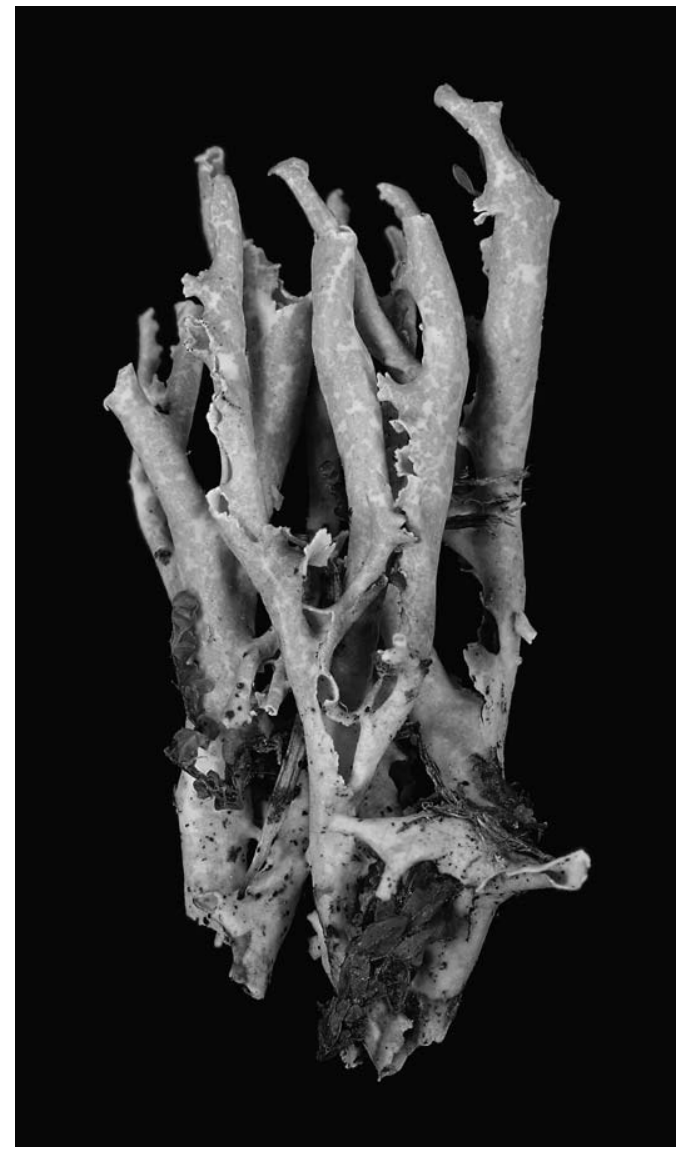

FIG. 4. Flavocetraria minuscula, Verkhoyansk District, Russia, 31 vii 2006, Ahti 64946 (LD-1154094, dupl. ex $\mathrm{H}), \times 4$.

Flavocetraria minuscula is included in a separate clade within the Cetraria s. lat. clade, composed of taxa having, with one exception, conidia with one thickening. Unfortunately the conidia of $F$. minuscula have yet to be observed. Ultimately, the conidial shape may confirm the unexpected phylogenetic position of $F$. minuscula distant from $F$. cucullata, a species characterized by dumb-bell shaped conidia.

'Melanelia' sorediella (Lettau) V. F. Rico, van den Boom E Barrasa

'Melanelia' sorediella, formerly known as Cetraria commixta f. sorediella, was raised to 


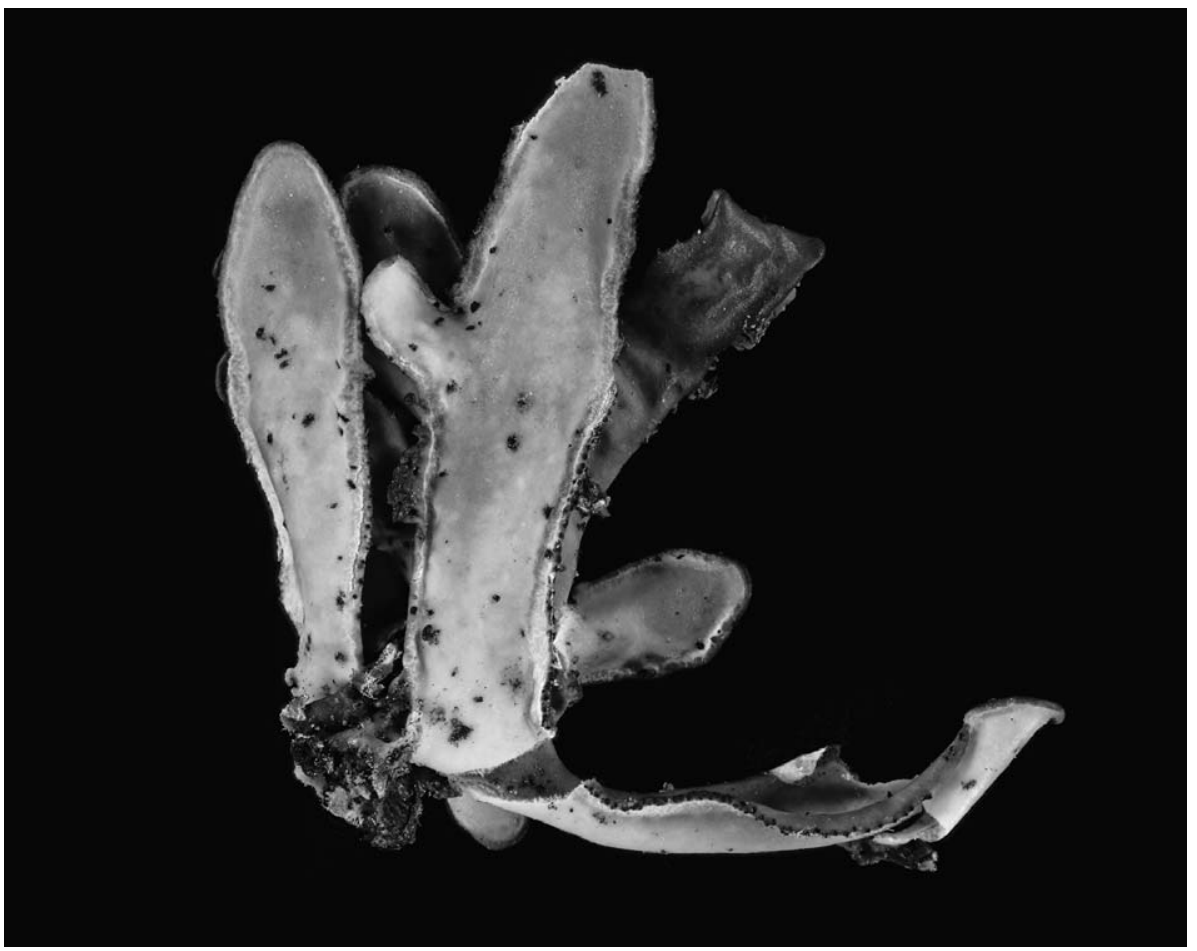

FIG. 5. Tuckermanopsis inermis, Noatak National Preserve, Alaska, 12 vii 2005, Holt 23441 (LD-1190038, dupl. ex OSU),$\times 7$

species level because of the presence of pycnoisidia and the absence of pseudocyphellae and apothecia (Rico et al. 2005). Cetraria commixta was previously transferred to Melanelia because of similarities in reproductive structures and other anatomical characters (Thell 1995a), and later to Cetrariella based on DNA analyses (Thell et al. 2004). The conidia of ' $M$ '. sorediella are citriform like those of the closely related Cetrariella commixta. Rico et al. (2005) hesitated about the taxonomic position of ' $M$ '. sorediella, and the present placement in Melanelia remains tentative due to the large phylogenetic distance between Melanelia and Cetrariella. Results of this study demonstrate that Cetrariella commixta and 'Melanelia' sorediella should belong to the same genus while the exact phylogenetic position of these two taxa remains unresolved.
Tuckermannopsis inermis (Nyl.) Kärnefelt

Except for their similar arctic, northernBeringian distribution, the most closely related species, Masonhalea richardsonii, shares no structural or chemical characters with Tuckermannopsis inermis (Kärnefelt 1977a; 1979). The pseudocyphellae are conspicuous in both species, forming unique, large decorticate patches on the lower side of $M$. richardsonii, and a continuous line close to the margin of the lower side of $T$. inermis (Fig. 5).

\section{Conclusions}

The interpretation of molecular phylogenetic studies in taxonomy is still in an initial phase. In Parmeliaceae, some new monophyletic groups have been detected and some superfluous genera have been synonymized 
(Blanco et al. 2004a; b). However, after four decades of splitting, a trend towards larger genera has more recently been adopted in the Parmeliaceae (Divakar et al. 2005, 2006; Wirtz et al. 2006).

The morphological, anatomical and chemical variation in the cetrarioid core is probably as large as in the Xanthoparmelia clade, although the conidial variation is greater among the cetrarioid lichens. Today, Xanthoparmelia (Vain.) Hale is a genus of approximately 800 species comprising eight previously accepted genera, a clade supported by the presence of Xanthoparmeliatype lichenan in the cell walls (Prado et al. 2007; Thell et al. 2006). The second largest genus of the family, Usnea Adans., is characterized by a dense cord in the medulla and comprises up to 600 species after the inclusion of Neuropogon and Protousnea (Wirtz et al. 2006).

Polyphyletic genera in the cetrarioid core could, in some cases, be eliminated or adjusted by using alternative, previously published combinations. However, neither the whole cetrarioid core nor either of the main clades (A \& B) can be defined by any presently known non-molecular characters. The general shape of conidia (with one swelling versus two swellings) corresponds, with some exceptions (Fig $1 \& 2$ ), to the division of the cetrarioid core into two major groups, Cetraria s. lat. and Nephromopsis s. lat. The only alternative to the multi-generic concept proposed here, where smaller monophyletic clades are accepted as genera (albeit nested within larger, paraphyletic genera), would be to name the whole cetraroid core Cetraria, despite the lack of any known correlating characters.

The work was supported financially by the Academy of Finland (grants 44079, 52262 and 211172), the Ove Almborn's Foundation, the Estonian Science Foundation (grant 7470), the European Union through the European Regional Development Fund (Centre of Excellence FIBIR) and funding from the Faculty of Science for IK. We are grateful to Patrik Frödén for taking the photographs, Emily Holt and Gennadij Urbanavicius for collecting species not sequenced previously, and Jolanta Miądlikowska for providing an ITS sequence of Tuckermannopsis ciliaris from the AFTOLproject.

\section{REFERENCES}

Arup, U., Ekman, S., Grube, M., Mattsson, J.-E. \& Wedin, M. (2007) The sister group relation of Parmeliaceae (Lecanorales, Ascomycota). Mycologia 99: 42-49.

Blanco, O., Crespo, A., Divakar, P. K., Elix, J. A., Hawksworth, D. L. \& Lumbsch, H. T. (2004a) A molecular phylogeny and a new classification of parmelioid lichens containing Xanthoparmelia-type lichenan (Ascomycota: Lecanorales). Taxon 53: 959-975.

Blanco, O., Crespo, A., Divakar, P. K., Esslinger, T. L., Hawksworth, D. L. \& Lumbsch, H. T. (2004b) Melanelixia and Melanohalea, two new genera segregated from Melanelia (Parmeliaceae) based on molecular data. Mycological Research 108: 873-884.

Blanco, O., Crespo, A., Divakar, P. K., Elix, J. A. \& Lumbsch, H. T. (2005) Molecular phylogeny of parmotremoid lichens (Ascomycota, Parmeliaceae). Mycologia 97: 150-159.

Blanco, O., Crespo, A., Ree, R. H. \& Lumbsch, H. T. (2006) Major clades of parmelioid lichens (Parmeliaceae, Ascomycota) and the evolution of their morphological and chemical diversity. Molecular Phylogenetics and Evolution 39: 52-69.

Crespo, A., Lumbsch, H. T., Mattsson, J.-E., Blanco, O., Divakar, P. K., Articus, K., Wiklund, E., Bawingan, P. A. \& Wedin, M. (2007) Testing morphology-based hypotheses of phylogenetic relationships in Parmeliaceae (Ascomycota) using three ribosomal markers and the nuclear RPB1 gene. Molecular Phylogenetics and Evolution 44: 812 824.

Divakar, P. K., Crespo, A., Blanco, O. \& Lumbsch, H. T. (2006) Phylogenetic significance of morphological characters in the tropical Hypotrachyna clade of parmelioid lichens (Parmeliaceae, Ascomycota). Molecular Phylogenetics and Evolution 40: 448-458.

Divakar, P. K., Molina, M. C., Lumbsch, H. T. \& Crespo, A. (2005) Parmelia barrenoae, a new lichen species related to Parmelia sulcata (Parmeliaceae) based on molecular and morphological data. Lichenologist 37: 37-46.

Egan, R. S. (1987) A fifth checklist of the lichenforming, lichenicolous and allied fungi of the continental United States and Canada. Bryologist 90: 77-173.

Ekman, S. (2001) Molecular phylogeny of the Bacidiaceae (Lecanorales, lichenized Ascomycota). Mycological Research 105: 783-797.

Elix, J. A. (1993) Progress in the generic delimitation of Parmelia sensu lato lichens (Ascomycotina: Parmeliaceae). Bryologist 96: 359-383.

Elix, J. A., Tønsberg, T. \& Wardlaw, J. H. (2004) The structure of friesiic acid, a novel lichen substance from Hypocenomyce friesii. Bibliotheca Lichenologica 88: 103-109.

Esslinger, T. L. (2003) Tuckermanella, a new cetrarioid genus in western North America. Mycotaxon 85: 135-141. 
Gardes, M. \& Bruns, T. D. (1993) ITS primers with enhanced specificity for basidiomycetes. Application to the identification mycorrhizae and rusts. Molecular Ecology 2: 113-118.

Goward, T. (1985) Ahtiana, a new lichen genus in the Parmeliaceae. Bryologist 88: 367-371.

Hafellner, J. (1984) Studien in Richtung einer naturlicheren Gliederung der Sammelfamilien Lecanoraceae und Lecideaceae. Nova Hedwigia 79: 241-371. Vaduz: J. Cramer.

Henssen, A. \& Jahns, H. M. (1974) Lichenes. Stuttgart: G. Thieme.

Kärnefelt, I. (1977a) Masonhalea, a new lichen genus in the Parmeliaceae. Botaniska Notiser 130: 101-107.

Kärnefelt, I. (1977b) Three new species of brown fruticose Cetraria. Botaniska Notiser 130: 125-129.

Kärnefelt, I. (1979) The brown fruticose species of Cetraria. Opera Botanica 46: 1-150.

Kärnefelt, I. (1986) The genera Bryocaulon, Coelocaulon and Cornicularia and formerly associated taxa. Opera Botanica 86: 1-90.

Kärnefelt, I., Mattsson, J.-E. \& Thell, A. (1992) Evolution and phylogeny of cetrarioid lichens. Plant Systematics and Evolution 183: 113-160.

Kärnefelt, I., Mattsson, J.-E. \& Thell, A. (1993) The lichen genera Arctocetraria, Cetraria and Cetrariella (Parmeliaceae) and their presumed evolutionary affinities. Bryologist 96: 394-404.

Kärnefelt, I. \& Thell, A. (1992) The evaluation of characters in lichenized families, exemplified with the alectorioid and some parmelioid genera. Plant Systematics and Evolution 180: 181-204.

Kärnefelt, I. \& Thell, A. (1993) Chemical evolution in cetrarioid lichens. Bibliotheca Lichenologica 53: 115127.

Kärnefelt, I. \& Thell, A. (1994) Sexual reproductive characters vs. morphological characters in lichen genera. Fournal of the Hattori Botanical Laboratory 76: $207-219$.

Kärnefelt, I. \& Thell, A. (1996) A new classification for the Dactylina/Dufourea complex. Nova Hedwigia 62: 487-511.

Kärnefelt, I. \& Thell, A. (2001) Delimitation of the genus Tuckermannopsis Gyeln. (Ascomycotina, Parmeliaceae) based on morphology and DNA sequences. Bibliotheca Lichenologica 78: 193-209.

Kärnefelt, I., Thell, A., Randlane, T. \& Saag, A. (1994) The genus Flavocetraria Kärnefelt \& Thell (Parmeliaceae, Ascomycotina) and its affinities. Acta Botanica Fennica 150: 79-86.

Kurokawa, S. \& Lai, M. J. (1991) Allocetraria, a new lichen genus in the Parmeliaceae. Bulletin of the National Science Museum (Tokyo), Series B (Botany) 17: 59-65.

Lai, M. J. 1980. Studies on the cetrarioid lichens in Parmeliaceae of East Asia (I). Quarterly fournal of the Taiwan Museum 33: 215-229.

Lai, M. J. \& Elix, J. A. (2002) A new species of Cetreliopsis (Ascomycotina, Parmeliaceae) from Thailand. Mycotaxon 84: 355-360.

Lai, M. J., Qian, Z. G. \& Xu, L. (2007) Synopsis of the cetrarioid lichen genera and species (Parmeliaceae, lichenized Ascomycotina) in China. Fournal of the National Taiwan Museum 60: 45-61.

Larget, B. \& Simon, D. L. (1999) Markov chain Monte Carlo algorithms for the Bayesian analysis of Phylogenetic trees. Molecular Biology and Evolution 16: 750-759.

Lumbsch, H. T., Schmitt, I., Mangold, A. \& Wedin, M. (2007) Ascus types are phylogenetically misleading in Trapeliaceae and Agyriaceae (Ostropomycetidae, Ascomycota). Mycological Research 111: 11331141.

Mattsson, J.-E. (1993) A monograph of the genus Vulpicida (Parmeliaceae, Ascomycetes). Opera Botanica 119: $1-61$.

Mattsson, J.-E. \& Lai, M. J. (1993) Vulpicida, a new genus in Parmeliaceae (lichenized ascomycetes). Mycotaxon 46: 425-428.

Müller [Argoviensis], J. (1891) Lichenologische Beiträge 35. Flora (Regensburg) 74: 371-382.

Myllys, L., Lohtander, K. \& Tehler, A. (2001) $\beta$-tubulin, ITS and group I intron sequences challenge the species pair Physcia aipolia and P. caesia. Mycologia 93: 335-343.

Myllys, L., Stenroos, S. \& Thell, A. (2002) New genes for phylogenetic studies of lichenized fungi: glyceraldehyde-3-phosphate dehydrogenase and $\beta$-tubulin genes. Lichenologist 34: 237-246.

Obermayer, W. (2008) Fotografische Dokumentation einer ungewöhnlich reich fruchtenden Aufsammlung von Cetraria islandica (L.) Ach. [mit einem historischen Abriss zur Darstellung fertiler Thalli, Anmerkungen zur Gestalt der Pycnosporen und einigen Notizen zum Gebrauch des 'Kramperltees']. Mitteilungen des naturwissenschaftlichen Vereins für Steiermark 138: 113-158.

Ohmura, Y. (2002) Phylogenetic evaluation of infrageneric groups of the genus Usnea based on ITS regions in rDNA. Fournal of the Hattori Botanical Laboratory 92: 231-243.

Ohmura, Y. \& Kanda, H. (2004) Taxonomic status of section Neuropogon in the genus Usnea elucidated by morphological comparison and ITS rDNA sequences. Lichenologist 36: 217-225.

Oxner, A. N. (1933) Species Lichenum novae ex Asia. fournal du Cycle Botanique de l'Academie des Sciences d'Ukraine 2: 167-172.

Prado, R. del, Ferencová, Z., Armas-Crespo, V., Amo de Paz, G., Cubas, P. \& Crespo, A. (2007) The arachiform vacuolar body, an overlooked shared character in the ascospores of a large monophyletic group within Parmeliaceae (Xanthoparmelia clade, Lecanorales). Mycological Research 91: 455-467.

Randlane, T. \& Saag, A. (1998) Synopsis of the genus Nephromopsis (fam. Parmeliaceae, lichenized Ascomycota). Cryptogamie, Bryologie-Lichénologie 19: $175-191$.

Randlane, T. \& Saag, A. (2000) Revision of the second updated world list of cetrarioid lichens. January 17, 2002. http://www.ut.ee/lichens/cetraria.html

Randlane, T. \& Saag, A. (2003) Taxonomic notes on some cetrarioid lichens. Mycotaxon 87: 479-487. 
Randlane, T. \& Saag, A. (2004) Distribution patterns of some primary and secondary cetrarioid species. Acta Universitatis Upsaliensis Symbolae Botanicae Upsalienses 34: 359-376.

Randlane, T. \& Saag, A. (2005) Distribution patterns of primary and secondary species in the genus Vulpicida. Folia Cryptogamica Estonica 41: 89-96.

Randlane, T., Saag, A. \& Obermayer, W. (2001) Cetrarioid lichens containing usnic acid from the Tibetan area. Mycotaxon 80: 389-425.

Randlane, T., Saag, A. \& Thell, A. (1997) A second updated world list of cetrarioid lichens. Bryologist 100: $109-122$.

Randlane, T., Thell, A. \& Saag, A. (1995) New data about the genera Cetrariopsis, Cetreliopsis and Nephromopsis (fam. Parmeliaceae, lichenized Ascomycotina). Cryptogamie, Bryologie-Lichénologie 16: 3560.

Rico, V. J., van den Boom, P. P. G. \& Barrasa, J. M. (2005) Morphology, chemistry and distribution of Melanelia sorediella (Parmeliaceae) and similar species in the Iberian Peninsula. Lichenologist 37: 199-215.

Saag, A., Randlane, T., Thell, A. \& Obermayer, W. (2002) Phylogenetic analysis of cetrarioid lichens with globose ascospores. Proceedings of the Estonian Academy of Sciences, Biology, Ecology 51: 103-123.

Swofford, D. L. (1998) PAUP: Phylogenetic Analysis Using Parsimony, Version 4.0b. Sunderland, Mass.: Sinauer Associates.

Thell, A. (1995a) A new position of the Cetraria commixta group in Melanelia (Ascomycotina, Parmeliaceae). Nova Hedwigia 60: 407-422.

Thell, A. (1995b) Pycnoconidial types and their presence in cetrarioid lichens (Ascomycotina, Parmeliaceae). Cryptogamie, Bryologie-Lichénologie 16: 247-256.

Thell, A. (1998) Phylogenetic relationships of some cetrarioid species in British Columbia with notes on Tuckermannopsis. Folia Cryptogamica Estonica 32: 113-122.

Thell, A. (1999) Group I intron versus ITS sequences in phylogeny of cetrarioid lichens. Lichenologist 31: 441-449.

Thell, A., Feuerer, T., Elix, J. A. \& Kärnefelt, I. (2006) A contribution to the phylogeny and taxonomy of Xanthoparmelia (Ascomycota, Parmeliaceae). Fournal of the Hattori Botanical Laboratory 100: 797-807.

Thell, A., Feuerer, T., Kärnefelt, I., Myllys, L. \& Stenroos, S. (2004) Monophyletic groups within the Parmeliaceae identified by ITS rDNA, betatubulin and GAPDH sequences. Mycological Progress 3: $297-314$

Thell, A. \& Goward, T. (1996) The new cetrarioid genus Kaernefeltia and related groups in the Parmeliaceae (lichenized Ascomycotina). Bryologist 99: 125-136.
Thell, A., Goward, T., Randlane, T., Kärnefelt, I. \& Saag, A. (1995a) A revision of the North American lichen genus Ahtiana (Parmeliaceae). Bryologist 98: 596-605.

Thell, A., Mattsson, J.-E. \& Kärnefelt, I. (1995c) Lecanoralean ascus types in the lichenized families Alectoriaceae and Parmeliaceae. Cryptogamic Botany 5: 120-127.

Thell, A. \& Miao, V. (1998) Phylogenetic analysis of ITS and group I intron sequences from European and North American samples of cetrarioid lichens. Annales Botanici Fennici 35: 275-286.

Thell, A., Randlane, T., Kärnefelt, I., Gao, X.-Q. \& Saag, A. (1995b) The lichen genus Allocetraria (Ascomycotina, Parmeliaceae). In Flechten Follmann. Contributions to Lichenology in Honour of Gerhard Follmann (J. A. Daniels, M. Schulz \& J. Peine, eds): 353-370. Cologne: University of Cologne.

Thell, A., Randlane, T., Saag, A. \& Kärnefelt, I. (2005) A new circumscription of the lichen genus Nephromopsis (Parmeliaceae, lichenized Ascomycetes). Mycological Progress 4: 303-316.

Thell, A., Søchting, U., Kärnefelt, I., Elix, J. A. \& Sancho, L. G. (2007) Phylogeny of Himantormia an Antarctic genus in the Parmeliaceae (lichenized ascomycetes). Bibliotheca Lichenologica 95: 95-541.

Thell, A., Stenroos, S., Feuerer, T., Kärnefelt, I., Myllys, L. \& Hyvönen, J. (2002) Phylogeny of cetrarioid lichens (Parmeliaceae) inferred from ITS and $\beta$-tubulin sequences, morphology, anatomy and secondary chemistry. Mycological Progress 1: 335-354.

Thell, A., Stenroos, S. \& Myllys, L. (2000) A DNAstudy of the Cetraria aculeata and C. islandica groups. Folia Cryptogamica Estonica 36: 95-106.

van den Boom, P. P. G. \& Sipman, H. J. M. (1994) Cetraria obtusata comb. et stat nov., an overlooked lichen species from the central Alps. Lichenologist 26: 105-112.

White, T. J., Burns, T., Lee, S. \& Taylor, J. W. (1991) Amplification and direct sequencing of fungal ribosomal RNA genes for phylogenetics. In PCR Protocols: a Guide to Methods and Applications (M. A. Innis, D. H. Gelfand, J. J. Sninsky \& T. J. White, eds): 315-322. San Diego: Academic Press.

Wirtz, N., Printzen, C., Sancho, L. G. \& Lumbsch, H. T. (2006) The phylogeny and classification of Neuropogon and Usnea (Parmeliaceae, Ascomycota) revisited. Taxon 55: 367-376.

Zhurbenko, M. P., Laursen, G. A. \& Walker, D. A. (2005) New and rare lichenicolous fungi and lichens from the North American Arctic. Mycotaxon 92: 201-212.

Zoller, S., Scheidegger, C. \& Sperisen, C. (1999) PCRprimers for the amplification of mitochondrial small subunit ribosomal DNA of lichen-forming ascomycetes. Lichenologist 31: 511-516. 